Research, part of a Special Feature on Sustainable Land-Use Practices in Mountain Regions: Integrative Analysis of Ecosystem Dynamics Under Global Change, Social-Economic Impacts, and Policy Implications

\title{
Past and future landscape dynamics in pasture-woodlands of the Swiss Jura Mountains under climate change
}

\author{
$\underline{\text { Alexander Peringer }}_{1,7}^{1,2}, \underline{\text { Silvana Siehoff }}^{1,3}, \underline{\text { Joël Chételat }}^{4}, \underline{\text { Thomas Spiegelberger }}^{1,5}, \underline{\text { Alexandre Buttler }}^{1,6}$ and $^{\text {François Gillet }}$
}

\begin{abstract}
Silvopastoral systems are traditional components of the landscape in the Swiss Jura Mountains, and are promising approaches for the sustainable management of mountain areas worldwide. Due to complex vegetation dynamics, pasturewoodlands are very vulnerable to the currently occurring land use and climate changes. Therefore, management requires integrative long-term predictions of successional trends. We present a refined version of the spatially explicit, dynamic simulation model WoodPaM with improved climate sensitivity of simulated vegetation. We investigate pasture-woodland dynamics by applying an innovative combination of retrospective simulations starting in the Middle Ages with prospective simulations following two climate change scenarios. The retrospective simulations demonstrate the strong dependency of the landscape mosaic on both climate and management. In high elevation mountain pastures, climate cooling during the Little Ice Age hindered simulated tree regeneration and reduced forage production of grasslands. Both led to an increase in open grassland and to a structural simplification of the landscape. In turn, climate warming afterwards showed the opposite effect. At lower elevations, high cattle stocking rates generally dominate simulated succession, leading to a slow development of quite homogenous landscapes whose structures are hardly affected by historical climate variability. Aerial photographs suggest that logging and windstorms critically shaped the current landscape, both homogenizing mosaic structures that emerge from selective grazing. Simulations of climate change scenarios suggest delayed but inevitable structural changes in the landscape mosaic and a temporary breakdown of the ecosystem service wood production. The population of currently dominating Norway spruce collapses due to simulated drought. Spruce is only slowly replaced either by beech under moderate warming or by Scots pine under extreme warming. In general, the shift in tree species dominance results in landscapes of less structural richness than today. In order to maintain the mosaic structure of pasture-woodlands, we recommend a future increase in cattle stocking on mountain pastures. The (re-) introduction of mixed herds (cattle with horses, sheep, and goats) could mitigate the simulated trend towards structural homogenization of the forest-grassland mosaic because diverse browsing effects selectively control tree regeneration and would counteract simulated forest encroachment. This could prevent the loss of species-rich open grasslands and forest-grassland ecotones. Forest management should respect forest-grassland mosaics and ecotones by following the traditional selective felling of single trees instead of large clear-cutting. Additionally, beech regeneration should be promoted from now on in order to smoothen tree species replacement with warming and to ensure the continuous provision of forest ecosystem services.
\end{abstract}

Key Words: climate warming; landscape structure; management; pasture-woodland; silvopastoral system; species shift; retrospective simulation; vegetation dynamics

\section{INTRODUCTION}

In most developed countries, the intensification of agriculture has generally resulted in landscape changes from smallgrained heterogeneous patterns towards more monotonous and mono-functional landscapes (Brandt 2003). Particularly, the multifunctional pasture-woodlands of Western Europe are threatened by a strong tendency towards segregation of land use (van Lier 1998), which leads to the spatial and functional isolation of large patches of intensively used grasslands from forests. Pasture-woodlands are ecosystems of high conservation value (Olff and Ritchie 1998, Svenning 2002, Poschlod et al. 2005, Kleyer et al. 2007) and serve as refuge habitats for threatened species because of their richness in vegetation types embedded into a dynamic forest-grassland mosaic. Furthermore, silvopastoral systems are among the most promising approaches for sustainable management of mountain areas worldwide (Etienne 1996, Mosquera-Losada et al. 2005).

Pasture-woodlands are dynamic systems with progressive and regressive successions being driven by the grazing impacts of cattle. The landscape structure is a dynamic patch-mosaic of different successional stages between grassland and woodland (Olff et al. 1999, Mouissie et al. 2008). In mountain pastures, vegetation dynamics are very slow because of the longevity

\footnotetext{
${ }^{1}$ Ecole Polytechnique Fédérale de Lausanne EPFL, School of Architecture, Civil and Environmental Engineering ENAC, Laboratory of Ecological Systems ECOS, Switzerland, ${ }^{2}$ University of Stuttgart, Institute for Landscape Planning ILPO, Germany, ${ }^{3}$ Aachen University RWTH, Research Institute for Ecosystem Analysis and Assessment (gaiac), Germany, ${ }^{4}$ Microgis Foundation for Spatial Analysis MFSA, St-Sulpice, Switzerland, ${ }^{5}$ IRSTEA, Research Unit Mountain Ecosystems, Saint-Martin d'Hères, France, ${ }^{6}$ Swiss Federal Institute for Forest, Snow and Landscape Research WSL, Switzerland, ${ }^{7}$ Université de Franche-Comté CNRS, Chrono-environnement, France
} 
of trees and the harsh climate. As a consequence, the impact of management actions and climate change on landscape structure may be delayed for decades. Nevertheless, due to the complex interactions that drive the dynamics of the grasslandforest mosaic, pasture-woodlands are supposed to be very vulnerable to the currently occurring coincidence of land use and climate changes (Buttler et al. 2009). Overall, livestock stocking rate and climate both directly influence the establishment of trees, and their regeneration is a critical stage in grazed systems (Vandenberghe 2006, Vandenberghe et al. 2007, 2008) that determines landscape structure in the long run. Moreover, climate also determines forage production of the herb layer, which influences the spatial pattern of cattle activities such as grazing, dunging, trampling, and browsing (Kohler et al. 2006). Considering such feedback loops and the unknown balance of counteracting processes, integrative longterm predictions of successional trends are required to support management decisions (Swetnam et al. 1999).

In the Swiss Jura Mountains, pasture-woodlands represent a traditional form of seminatural landscape that is rich in biodiversity (Gillet et al. 1999, Dufour et al. 2006). They depend on multiple and extensive land use, including cattle stocking (cows, heifers, and calves) and logging, that is still practiced or has been practiced until recent times. During the last century, socioeconomic constraints on agriculture in mountain areas have changed considerably, which has affected both qualitative and quantitative aspects of silvopastoral management (Huber et al. 2013) and landscape structure (Chételat et al. 2013). However, time series of aerial photographs can show only the combined consequences of recent land use extensification and climate warming, i.e., forest encroachment (Béguin 2007) and homogenization of the grassland-forest mosaic during the last century (Chételat et al. 2013). The impacts of these two factors have not been disentangled yet.

Thanks to many previous research projects on pasturewoodlands in the Jura Mountains, the interactions between vegetation patterns, silvopastoral management, cattle activity, grassland dynamics, and tree regeneration are well known (Gillet and Gallandat 1996, Perrenoud et al. 2003, Buttler et al. 2009). The spatially explicit dynamic model WoodPaM (Gillet 2008) incorporates most of the processes necessary to predict the long-term impact of silvopastoral management and temperature increase on plant communities and cattle habitat use in heterogeneous pasture-woodlands. However, combined impacts of climate change (temperature rise, precipitation shift from summer to winter, and drought) were not implemented into this model, and simulation studies based on explicit time series of historical and projected climate have not been carried out yet.

We report recent refinements of WoodPaM that have been made to investigate climate change impacts on pasture- woodlands more explicitly. Based on the forest landscape model LandClim (Schumacher et al. 2004, 2006, Schumacher and Bugmann 2006), the climate sensitivity of simulated tree species has been improved. Based on newly established regressions, the delayed response of herb layer succession and productivity to climate warming has been implemented. With a retrospective analysis of the development of the grasslandforest mosaic in four pastures of the Jura Mountains since the Middle Ages (1100 AD) (Sjogren 2005, 2006), we assess the causal relationships between dynamics of land use, climate, and vegetation. Through simulations of two future scenarios of climate change (A1FI and B2 according to IPCC SRES 2000) we pinpoint future successional trends and the sensitivity of pasture-woodlands to climate change impacts. From this innovative combination of retrospective and prospective simulation experiments (Leeuw et al. 2011), we derive guidelines for future adaptive management of silvopastoral systems that aim at the maintenance of the landscape mosaic.

\section{METHODS}

\section{Model description}

WoodPaM (Gillet et al. 2002, Gillet 2008) is a spatially explicit model of pasture-woodland dynamics that is able to simulate the emergence of a semi-open landscape structure from the interactions between vegetation and large herbivores (cattle). During simulations, selective foraging of cattle causes local impacts on vegetation (grazing, browsing, trampling, and dunging), which in turn and together with the natural successional trend of forest development drive the dynamics of the landscape structure (Fig. 1).

In WoodPaM, a pasture is represented by a mosaic of square grid cells, each $25 \mathrm{~m}$ wide. Each cell features three landscape compartments, which are represented as submodels: the herb layer (consisting of four ecological community types: eutrophic pastureland $\mathrm{M}$, oligotrophic pastureland $\mathrm{L}$, fallow $\mathrm{F}$, and understory U), shrubs (gathering all kinds of mostly thorny shrubs, which are frequent on pastures and provide safe sites for tree recruitment through protection from browsing), and tree populations (13 species, divided into four life stages: seedlings, saplings, small trees, and big mature trees). At this cell level, another submodel represents local herbivore impacts (grazing, browsing, dunging, trampling). The intensity of herbivore impacts depends on the attractiveness of the grid cell for cattle. Local succession in the herb layer is driven by local intensity of grazing, trampling, dunging, and shading. Local woody plant succession is driven by seeding input, safe-site availability in the herb layer, and browsing intensity. Local successions within cells are influenced by neighboring cells through seed dispersal of trees (considering only the four adjacent cells orthogonally to the central cell) and are connected at paddock level by cattle behavior. Selective habitat use by cattle among cells within each 
paddock considers the attractiveness of each cell, which depends on local forage production, distance to watering points, tree cover, and geomorphology (slope, rock outcrops). We compute a local livestock density, which is high in attractive cells and leads to strong grazing impacts there, from which in turn treeless eutrophic pastures emerge. In unattractive cells, for example, on steep and rocky slopes, trees and shrubs can regenerate.

Fig. 1. Structure of the WoodPaM model and main interactions (arrows) among submodels (in horizontal direction) and across spatial scales (in vertical direction). Successions in the herb, the shrub, and the tree submodels are driven by grazing impacts and climate. Grazing intensity at the grid cell level is determined by selective habitat use of cattle at the landscape level. Local successions in turn feed back to landscape level by the formation of spatio-temporal patterns of forage availability and landscape structures.

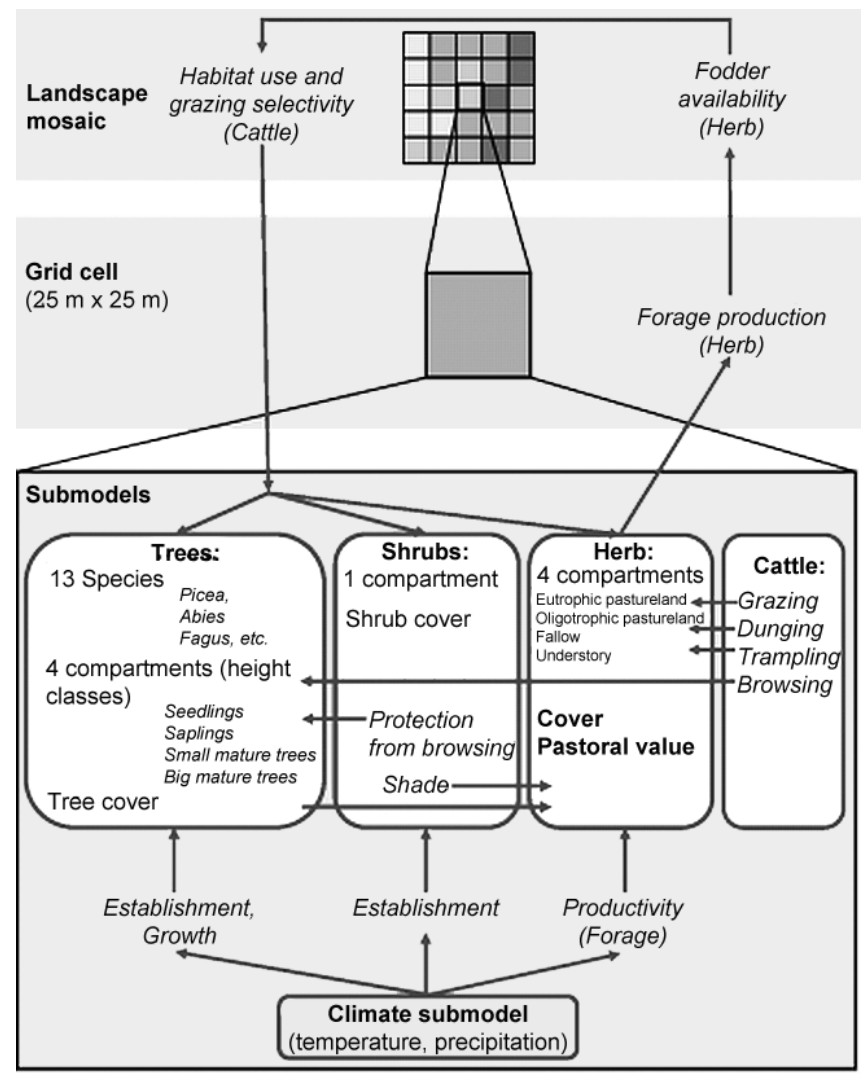

In order to simulate the dynamics of pasture-woodlands for alternative scenarios of climate change, we developed a climate submodel and refined the tree submodel, both based on the forest landscape model LandClim (Schumacher et al. 2004, 2006, Schumacher and Bugmann 2006). Climate impacts on tree establishment and growth in semi-open landscapes have been calibrated to the suboceanic climate prevailing in the Jura Mountains (Appendix). We introduced a delayed response of herb layer succession and forage production, taking into account that grassland plant communities slowly adapt to the general trend of temperature rise rather than spontaneously adapt to temperature fluctuations in single (warm) years.

For a detailed description of the first version of the model, we refer to Gillet (2008). All model refinements are presented in the Appendix.

\section{Design of simulations}

We applied the model to four pastures in the Jura Mountains. The study sites are located at different altitudes (1200 to 1350 meters above sea level [m a.s.l.]) and differ in land use history and current land use intensity (livestock management, logging) due to natural (topography) and socioeconomic constraints (distance to the closest village, proprietary). We performed a retrospective analysis of vegetation dynamics in the pastures since the Middle Ages (far past) using the results of a palaeoecological study in the same region (Sjogren 2005, 2006), as well as historical time series for stocking and climate (Moberg et al. 2005). We verified the model by comparing the outcome of our simulations with aerial photographs taken between 1934 and 2000 (for image processing, see Chételat et al. 2013). In one pasture, where historical data on logging and windstorms were available in the near past, we assessed the importance of logging and catastrophic events (storms) in explaining landscape structure.

Based on this thorough evaluation of our modeling approach, we simulated two future scenarios of climate change (IPCCSRES scenarios A1FI and B2), assuming the maintenance of current constraints on cattle stocking, in order to assess the sensitivity of the silvopastoral systems to climate change impacts.

\section{Simulated landscapes}

For the study sites, geomorphology (altitude, slope, curvature of the landscape surface, and rock outcrops) and farming constraints (stone walls and fences of pastures and paddocks, watering points) were arranged in a geographical information system and used to initialize the model.

While in historical simulations the pastures were simulated as a single management unit, for future scenarios, the pastures were divided into paddocks and a rotational grazing system was simulated because it has been the practice used since the 1970s. Table 1 summarizes this hierarchical structure of management units and provides information on historical and recent stocking rates used in simulations. Today, pastures are subdivided into sectors for each cattle herd, and each sector is subdivided into several paddocks. Stocking densities are expressed in livestock units (LU) per hectare, stocking periods in days per year, and stocking rates in $\mathrm{LU}$ day $\mathrm{ha}^{-1} \mathrm{yr}^{-1}$ (Allen et al. 2011). 
Table 1. Hierarchical structure of management units and corresponding historical and recent stocking rates. The complex of neighboring pastures Les Planets and Les Cluds is abbreviated as "Planets-Cluds," the pasture La Bullatonne-Dessous is abbreviated as "Bullatonne," and La Rionde-Dessus is abbreviated as "Rionde." Full names correspond to the Swiss National Map 1:25'000. Historical stocking in the Middle Ages is based on assumptions explained in the text. Stocking densities during the twentieth century are based on the FOAG $(1972,1974)$. The current stocking rate is calculated according to Allen et al. (2011) as the product of livestock units (LU) and grazing duration per year, divided by the grazed area.

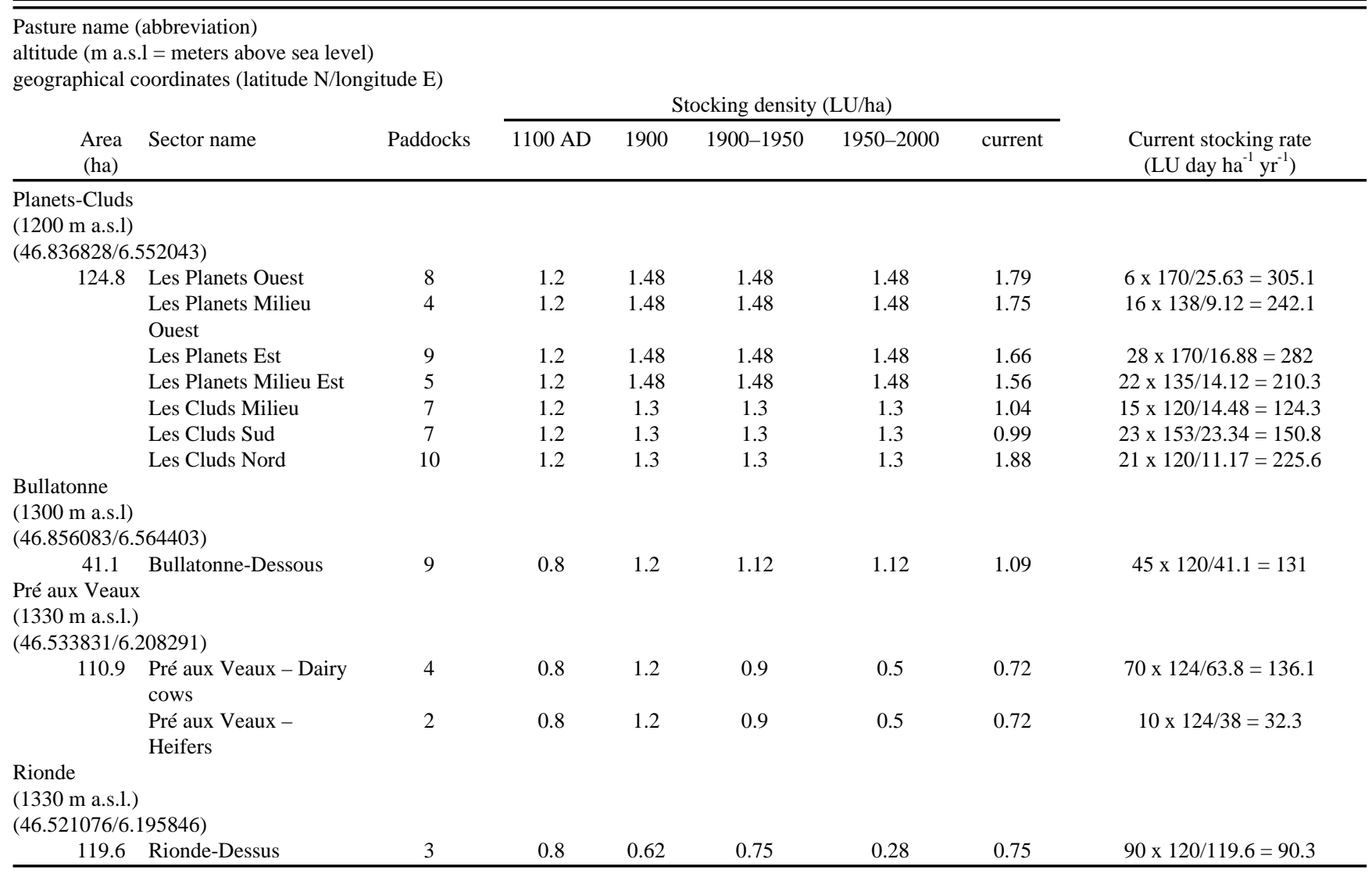

Information on logging and windstorms was available only for the pasture Rionde (Table 2).

\section{Time series of climate variability}

For retrospective simulations in the far past, we used a reconstructed climate time series (Fig. 2) starting from the Middle Ages (1100 AD) until today (2000 AD), which was compiled from two different sources. From 1100 until 1900 AD, a dendrochronological reconstruction of Northern Hemisphere temperature deviations from the 1961-1990 mean with yearly resolution was used (Moberg et al. 2005). In order to achieve monthly values required for simulation, seasonal temperature variability was generated based on regionalized monthly observed values of temperature from 1901 until 2000 (MPI-M 2006, 2009; D. Schmatz unpublished manuscript). Precipitation from 1100 AD until 1900 was a stochastically generated time series based on the observed data for the 1901-2000 period (monthly means and corresponding standard deviation). From 1901 on (near past), we explicitly used regionalized monthly observed values of temperature and precipitation. Future climate scenarios (Fig. 3) started with regionalized monthly temperature and precipitation time series for the 2001-2100 period according to two IPCC emission scenarios (A1FI and B2 [see IPCC SRES 2000, D. Schmatz unpublished manuscript]). Afterwards, a stochastic climate time series was generated based on the means of temperature and precipitation of the 2091-2100 period of each scenario and corresponding standard deviations. The two climate change scenarios pinpoint two extreme possible futures of our world: a fuel-intensive future with drastic warming (A1FI, approximately $+8 \mathrm{~K}$ from 2000 to 2100 [Fig. $3]$ ), and a moderate development with less warming (B2, approximately $+4 \mathrm{~K}$ from 2000 to 2100 [Fig. 3]). We assume the real development to be situated in the range between the two scenarios. 
Table 2. History of logging and windstorms in the pasture Rionde. Logging means cut off of standing trees and not exploitation of uprooted trees from windthrow. Especially during the Second World War, the wooded pastures were heavily exploited for fire wood. (Source: Forest Office, 14th Forestry District, St-George/Vaud, Switzerland)

\begin{tabular}{ccc}
\hline \hline Calendar year & Logged wood $\left(\mathrm{m}^{3}\right)$ & Windthrow $\left(\mathrm{m}^{3}\right)$ \\
\hline 1917 & 26 & \\
1918 & 54 & \\
1919 & 7 & \\
1920 & 267 & \\
1921 & 20 & \\
1922 & 19 & \\
1927 & 12 & \\
1937 & 117 & \\
1938 & 13 & \\
1940 & 57 & 425 \\
$1940-1950$ & 1943 & 456 \\
1941 & & \\
1946 & & \\
\hline
\end{tabular}

Fig. 2. Time series of historical climate (yearly values) used for simulation of the pasture's history since the Middle Ages. Temperature: black; precipitation: grey.

Dendrochronological reconstruction of temperature is from 1100 to $1900 \mathrm{AD}$ (Moberg et al. 2005), and regionalized observations are from 1900 to 2000 . The abrupt change in temperature variability in 1900 is an artifact, which results from the shift from reconstructed to observed temperature data. Given that this artificial temperature fluctuation is within the variability of the observed time series (see cool years around 1950), we do not expect an unrealistic bias in simulation results.

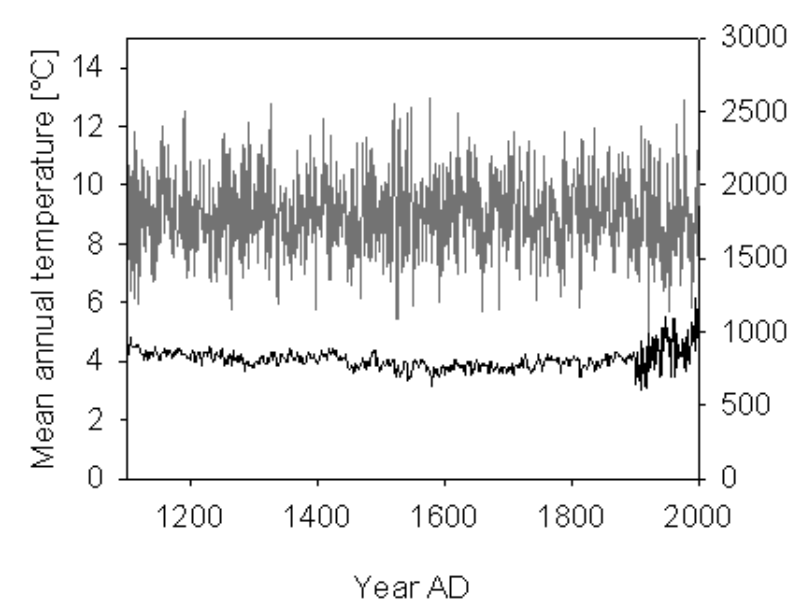

Fig. 3. Climate time series (mean annual temperatures and annual precipitation) for the two emission scenarios starting in 2000 and ending in 2100 (B2 left, A1FI right).

Temperature: black; precipitation: grey. After 2100, a stochastic climate time series was generated based on the temperature and precipitation means of the 2091-2100 period of each scenario and corresponding standard deviations.
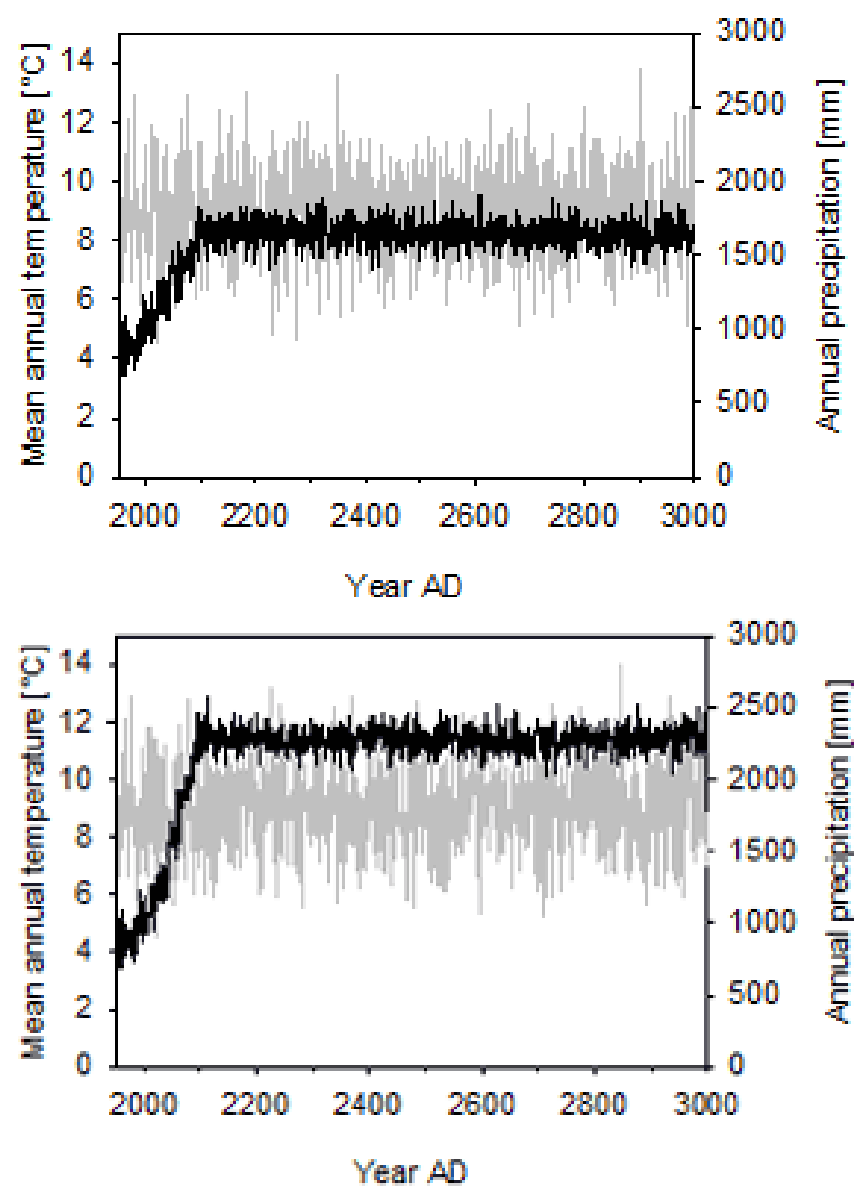

Observed climate data and climate change scenarios are based on regionalized climate data (data points in a grid of $100 \mathrm{~m}$ width). From this data set we use climate time series of one reference point located close to the study sites, while the climate submodel corrects for fine scale differences in altitude and exposition (slope, aspect) due to local conditions in the study sites.

\section{Landscape history in study sites}

Mosaic development since the Middle Ages (far past)

We performed a retrospective analysis of the historical emergence of the grassland-forest mosaic of the pastures 
between $1100 \mathrm{AD}$ and $2000 \mathrm{AD}$. The study design disentangles the synchronous effects of climate and land use change based on different rates of change of these two main drivers of vegetation dynamics. We simulated the development of the grassland-forest mosaic starting from an assumed clearing (random distribution of seedlings of all simulated tree species but no juvenile or adult trees). In order to separate the influence of climate variability and land use change on vegetation dynamics, we assumed a very slow and linear increase in stocking density between 1100 AD and 1900 AD (Table 1), whereas (reconstructed) climate time series is based on yearly fluctuating mean annual temperatures from $1100 \mathrm{AD}$ on (Fig. 2). In the twentieth century, observed stocking densities and observed climate applied. Logging and windstorms were not considered due to the lack of data over this long period of time.

By this means, our simulation results show the effects of historical climate variability (climate cooling during the Little Ice Age and warming afterwards, both within a few centuries) under contemporary but quasi static constraints: low stocking densities in the Middle Ages increase to observed densities very slowly (approximately $0.05 \mathrm{LU} / \mathrm{ha}$ in a century) based on assumed continuous improvements in agricultural practice, such as fertilization. Subsequently, when interpreting the simulation results, any shifts in the landscape mosaic within a time frame of centuries can clearly be dedicated to climatic fluctuations because simulated land use hardly changed over such a period of time. This procedure of disentangling two synchronously acting drivers of vegetation dynamics is additionally supported by the fact that historical climate change consists of alternating periods of cooling and warming and thus triggers corresponding regressive and progressive successions, while land use change is simulated as increasing unidirectionally, from which only one kind of system dynamics can emerge (either regressive or progressive-in our case, regressive). We compared the outcome of simulations to aerial photographs from the year 2000 (for details, see the Appendix).

Recent history of grazing, logging, and windstorms in the Rionde pasture (near past)

We used the synthesis of land use change and landscape structural development provided by Chételat et al. (2013) to further detail the retrospective analysis for the twentieth century (1934 AD_-2000 AD) and disentangle the effect of grazing from the combined effects of logging and windstorms. We simulated the development of the grassland-forest mosaic of the pasture Rionde based on a time series of grazing and climate alone and compared the results to aerial photographs taken in 1934, 1954, 1968, 1985, and 2000. Simulation started from the observed state of the forest-grassland mosaic in 1934. A model spin-up from 1900 until 1934 was performed and simulation proceeded until 2000. During spin-up, the model approximated the full demography of forest stands, especially the abundance of juvenile trees (old trees had been initialized from the aerial photograph interpretation) and the spatial configuration of herb layer compartments. Both processes reasonably reached equilibrium states within a few decades. The difference between simulated and observed pattern was interpreted as the impact of logging and windstorms on the mosaic development.

\section{Climate change scenarios for study sites}

We investigated successional dynamics in the pasture mosaics in the light of two climate change scenarios (B2 and A1FI, Fig. 3) and under the current grazing regime alone (without considering logging or windstorms). Stocking rates and the rotational system of cattle herding were fixed to the values and structures that had been observed around the year 2000 (Table 1). Accordingly, our simulations assumed agronomic business-as-usual, and undesirable simulation outcomes would reflect the need for adaptive management to face climate change. Simulation started from the observed state of the forest-grassland mosaic in 2000. Again, a model spin-up from 1950 until 2000 was performed. Simulations proceeded until calendar year 3000 in order to investigate long-term successional trends towards hypothetical equilibrium states of the system.

\section{Maps of simulated landscapes}

Although WoodPaM tracks the number of trees per grid cell, for visualization of landscape mosaics, four phytocoenosis types are used, which represented main plant communities associated with classes of tree cover (Table 3 ).

Table 3. Definition of the four main phytocoenosis types for structural classification of pasture-woodland vegetation (Gallandat et al. 1995).

\begin{tabular}{ll}
\hline \hline $\begin{array}{l}\text { Phytocoenosis } \\
\text { type }\end{array}$ & Description \\
\hline 1000 & $\begin{array}{l}\text { Unwooded pasture with tree cover less than } 1 \% \text {, trees or } \\
\text { bushes being mostly scattered } \\
\text { Sparsely wooded pasture with tree cover ranging between } \\
1 \% \text { and } 20 \%\end{array}$ \\
3000 & $\begin{array}{l}\text { Densely wooded pasture with tree cover ranging between } \\
20 \% \text { and } 70 \%\end{array}$ \\
4000 & $\begin{array}{l}\text { Grazed forest with tree cover greater than } 70 \%, \text { appearing } \\
\text { as forest with a closed canopy }\end{array}$ \\
\hline
\end{tabular}

\section{RESULTS}

\section{Historical analysis}

Comparison of long-term simulations with observed patterns in the year 2000 (far past)

The reconstruction of the current pasture-woodland mosaic from climate and grazing history since the Middle Ages delivered plausible results in the pastures Planets-Cluds, Bullatonne, and Pré aux Veaux, however not in Rionde (Fig. 
4). In Planets-Cluds, Bullatonne, and Pré aux Veaux, the simulated landscape structure fitted aerial photograph interpretation in the year 2000 generally well: we found densely wooded pasture in the less frequently grazed corners of the pastures and along ridges of rock outcrops.

Fig. 4. Long-term historical simulations (1100 AD-2000 $\mathrm{AD})$ and observed (2000 AD) landscape mosaics in the four pastures Planets-Cluds, Bullatone, Rionde, and Pré aux Veaux ( $\mathrm{m}$ a.s.l. $=$ meters above sea level). Squares represent 25-m grid cells used for both photo interpretation and model simulation. The four phytocoenosis types used for display are defined in Table 3.

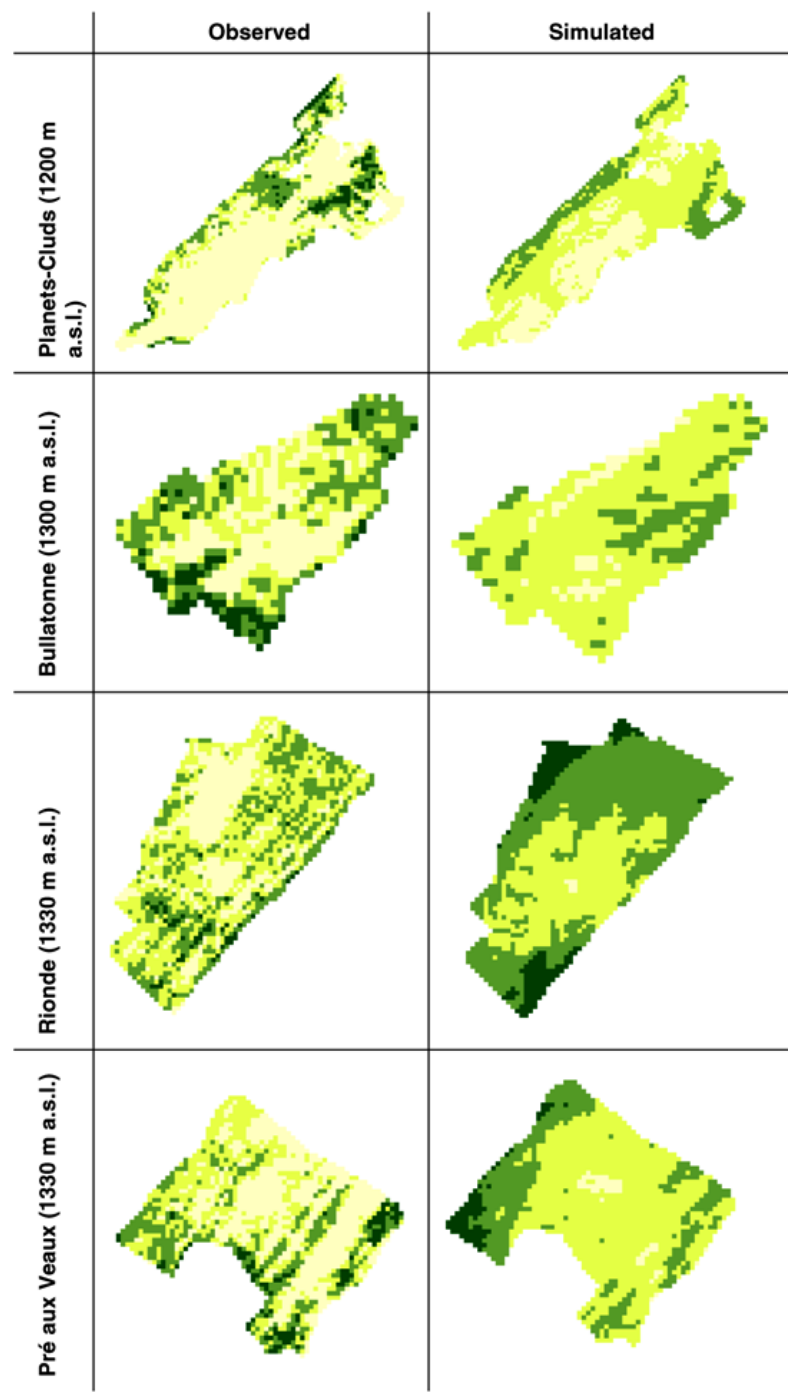

Unwooded pasture Sparsely wooded pasture
When comparing proportions of phytocoenosis types (for definitions, see Table 3) between simulated and observed landscapes, some important differences appeared, however (Table 4). Simulations of the Rionde pasture created far too densely wooded areas as compared to the observed pattern. In the pastures Planets-Cluds, Bullatonne, and Pré aux Veaux, the model simulated generally too much sparsely wooded pastures at the cost of unwooded pastures.

Table 4. Comparison of simulated and observed proportions of phytocoenosis types describing the composition of the landscape mosaic in each pasture at the end of simulations for retrospective analysis (calendar year 2000).

\begin{tabular}{lcccc}
\hline \hline & $\begin{array}{c}\text { Phytocoenosis } \\
\text { type }\end{array}$ & Observed & Simulated & $\begin{array}{c}\text { Difference } \\
\text { observed - } \\
\text { simulated }\end{array}$ \\
\hline Bullatonne & 1000 & $29.62 \%$ & $12.21 \%$ & $17.40 \%$ \\
& 2000 & $32.06 \%$ & $72.98 \%$ & $-40.92 \%$ \\
& 3000 & $27.79 \%$ & $14.81 \%$ & $12.98 \%$ \\
& 4000 & $10.53 \%$ & $0.00 \%$ & $10.53 \%$ \\
Planets- & & & & \\
Cluds & 1000 & $61.27 \%$ & $11.87 \%$ & $49.40 \%$ \\
& 2000 & $14.83 \%$ & $66.68 \%$ & $-51.85 \%$ \\
& 3000 & $18.29 \%$ & $21.29 \%$ & $-3.01 \%$ \\
Pré aux & 4000 & $5.61 \%$ & $0.15 \%$ & $5.46 \%$ \\
Veaux & & & & \\
& 1000 & $41.18 \%$ & $4.23 \%$ & $36.96 \%$ \\
& 2000 & $32.23 \%$ & $65.35 \%$ & $-33.13 \%$ \\
& 3000 & $20.62 \%$ & $25.52 \%$ & $-4.90 \%$ \\
Rionde & 4000 & $5.97 \%$ & $4.90 \%$ & $1.07 \%$ \\
& & & & \\
& 1000 & $27.12 \%$ & $0.10 \%$ & $27.01 \%$ \\
& 2000 & $46.34 \%$ & $32.81 \%$ & $13.53 \%$ \\
& 3000 & $24.45 \%$ & $55.85 \%$ & $-31.40 \%$ \\
& 4000 & $2.09 \%$ & $11.23 \%$ & $-9.14 \%$ \\
\hline & & & &
\end{tabular}

Landscape structural dynamics in the far past

The emergence of a well expressed pasture-woodland mosaic from open grassland alone is a process that takes centuries (Fig. 5). In our simulations, it took 100-150 years for the first densely wooded pasture to appear after clearing, which left tree regeneration to start from a random distribution of seedlings. The development of a complete mosaic consisting of some unwooded pastures, $75 \%$ of sparsely wooded pastures, $20-25 \%$ of densely wooded pastures, and some grazed forests (the latter in Pré aux Veaux and Rionde only) took about 400 years in extensively grazed mountain pastures (Bullatonne, Pré aux Veaux, and Rionde) and even longer under intensive grazing (Planets-Cluds).

In the extensively grazed mountain pastures (Bullatonne, Rionde, and Pré aux Veaux), forest regeneration (progressive succession) stopped around $1500 \mathrm{AD}$ with the beginning of the Little Ice Age. During the following centuries of cool 
Fig. 5. Landscape structural dynamics in long-term historical simulations of the pastures Bullatonne, Rionde, Pré aux Veaux, and Planets-Cluds. Simulations start from clearings in $1100 \mathrm{AD}$ and follow historical time series of grazing and climate. The four phytocoenosis types used for display are defined in Table 3. The landscape aggregation index AIL is computed after He et al. (2000) as the weighted mean of aggregation indexes AI computed for each phytocoenosis type. AI assumes that a class with the highest level of aggregation is comprised of pixels sharing the most possible edges (simple clumped pattern). A class whose pixels share no edges (completely disaggregated complex pattern) has the lowest level of aggregation.
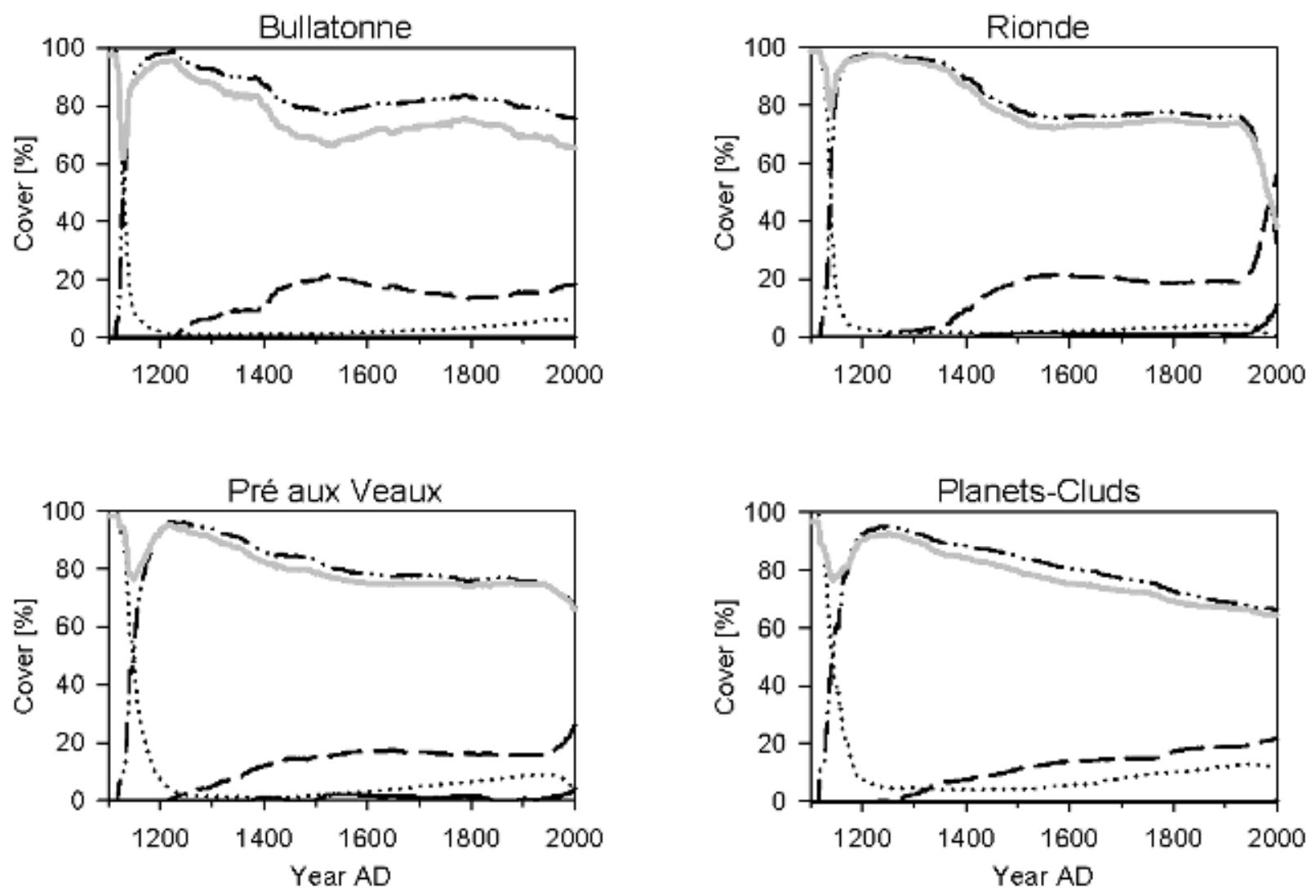

\begin{tabular}{|c|c|c|c|}
\hline Landscape structure: & $\begin{array}{l}\ldots \ldots \ldots . . \\
\text { - Unwooded pesture } \\
\text { - Densely wooded pasture }\end{array}$ & $-\cdots-$ & $\begin{array}{l}\text { Scarcelv wooded pasture } \\
\text { Grazed forest }\end{array}$ \\
\hline
\end{tabular}

climate, the cover of densely wooded pasture decreased (regressive succession). Sparsely wooded pastures dominated the pattern and open grasslands slightly increased. Recent climate warming from 1900 on triggered the inverse development in Rionde and Pré aux Veaux, i.e., densification of sparsely wooded pastures and forest encroachment at the cost of unwooded pastures. In Bullatonne, stocking remained constant during this period, and recent climate warming of 1 $\mathrm{K}$ promoted progressive succession only slightly. In Pré aux Veaux and Rionde, however, temporary extensification during the middle of the twentieth century, additional to warming (Table 1), led to a drastic increase in tree cover.
The intensively used pasture Planets-Cluds at lower altitude behaved differently: historical climate variability (warm Middle Ages vs. cool Little Ice Age) had little impact on the slow but continuous emergence of the mosaic. Landscape structural dynamics were governed by the slow increase in stocking density, which demanded a closely coupled increase in the cover of open grasslands. Interestingly, a slow but continuous segregation of the landscape into grassland and densely wooded pastures at the cost of sparsely wooded pastures was simulated.

As shown by the landscape aggregation index AIL (Fig. 5), the forest regeneration and mosaic development until 1500 
$\mathrm{AD}$ increased landscape structural diversity, indicated by a low AIL. During climate cooling, landscape structural diversity remained constant (Pré aux Veaux, Rionde) or decreased due to regressive forest succession (temporary increase in AIL in Bullatonne and Rionde). Recent climate warming from 1900 on positively contributed to landscape diversity, as the segregation into grassland and forest did in Planets-Cluds.

\section{Effects of logging and windstorms in the twentieth century (near past)}

When comparing simulated landscape dynamics during the twentieth century in the pasture Rionde with corresponding aerial photographs (Fig. 6), it became obvious that grazing and recent climate warming alone were not able to explain the currently observed open state of the pasture. The simulations showed a slow maturing of the landscape mosaic to a diverse pattern following geomorphological conditions and driven by cattle behavior (forest developed in the corners of the pasture, along fences and on rocky ridges). To the contrary, aerial photographs showed a decrease in forest cover from 1934 until 1968 and from 1985 until 2000, with an increase in between. Data on logging and windstorms (Table 2) from Chételat et al. (2013) showed that in these two time intervals, the landscape development was disturbed, the landscape mosaic was homogenized, and the diversification trend shown by simulations was overrun. In between (1968-1985), reduced logging intensity and extensification of grazing was followed by forest encroachment (Chételat et al. 2013), which allowed the emergence of a typical mosaic pattern again. Recent logging between 1985 and 2000 in the north of the pasture did not wipe out this pattern completely, as storms and intense logging did in the first half of the twentieth century. Forest cover was reduced selectively, turning dense (old) stands of trees (grazed forest) into lighter stands (densely wooded pasture). In the south of the pasture, densely wooded pasture was allowed to mature to grazed forest.

\section{Climate change scenarios}

The simulations showed that the future landscape structure and vegetation types strongly depend on the degree of simulated climate warming (Fig. 7, Fig. 8; cattle stocking densities were held constant during simulations), while until 2150 , only minor changes occurred with transformations of unwooded pastures into sparsely wooded pastures (Bullatonne and Planets-Cluds) and densification of densely wooded pastures into grazed forests (Pré aux Veaux). This initial phase of forest encroachment was initiated by both the contemporary climate warming from 1950 until 2000 during model spin-up and the climate warming during the first half of the twentyfirst century, which facilitated establishment and growth of spruce. Afterwards, successional trajectories diverged according to the degree of warming. By this period, in the moderate scenario B2, sparsely wooded pastures transformed into densely wooded pastures. Grazed forests
Fig. 6. Short-term historical simulations (1934 AD-2000 AD) and observed (2000 AD) landscape mosaics in the pasture Rionde during the twentieth century. The simulation outcome for year 2000 differs from the simulation outcome of the long-term historical simulations (Fig. 4) because we started the short-term simulation from a detailed interpretation of aerial photographs (Chételat et al. 2012). The fine-scale patterns persisted during the simulation of the twentieth century but were not simulated with the same precision since the Middle Ages. The four phytocoenosis types used for display are defined in Table 3; a legend is provided with Fig. 4.

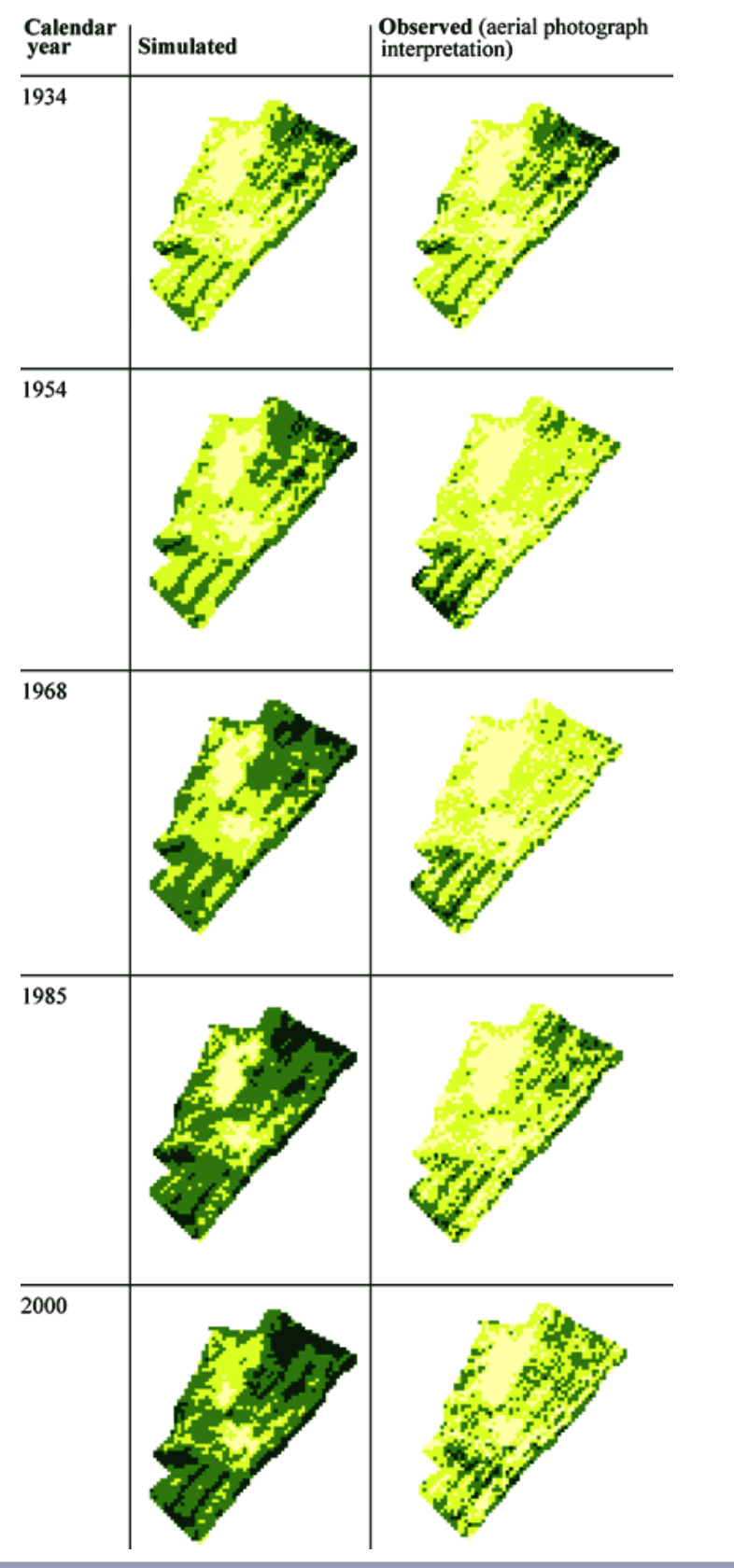


developed centuries later (2400 in Bullatonne, 2450 in PlanetsCluds), with the extensive mountain pasture Pré aux Veaux being the exception (2150). In the extreme warming scenario A1FI, however, forests as well as densely wooded pastures decreased after 2150 and sparsely wooded pastures temporarily dominated (around year 2200). From 2250 on, densely wooded pastures developed to high cover. In both scenarios, progressive forest succession took place in the long run, however towards very different forest types and landscape patterns: in the B2 scenario, a segregation into grazed forest and sparsely wooded pastures with some open grasslands took place, while in the A1FI scenario, grazed forests and open grassland did not develop even after 1000 simulation years (calendar year 3000) and the mosaic turned into a homogenous landscape consisting of densely wooded pastures only (Fig. 8).

Fig. 7. Landscape structural dynamics following climate change in the wooded pastures Planets-Cluds, Bullatonne, and Pré aux Veaux (m a.s.l. = meters above sea level). The four phytocoenosis types used for display are defined in Table 3. The pasture Rionde was not simulated because it is located at the same altitude as Pré aux Veaux. The landscape aggregation index AIL is defined in the caption of Fig. 5.

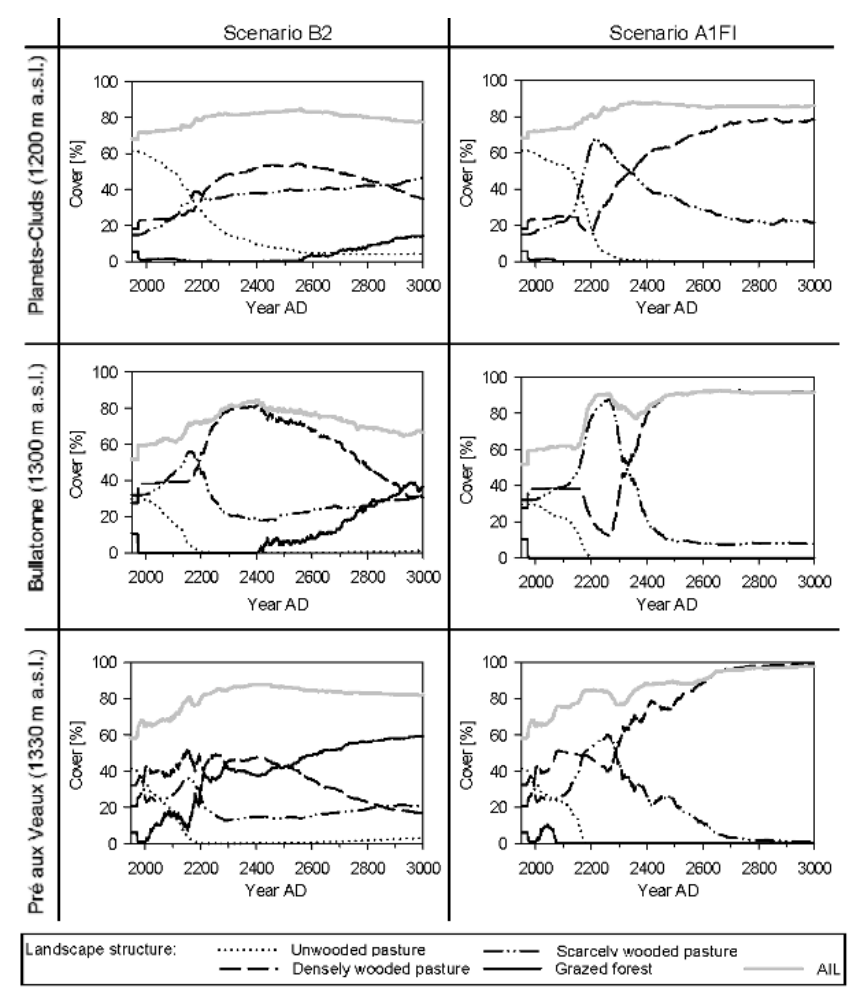

Fig. 8. Landscape structural changes in the climate change scenarios B2 and A1FI in Planets-Cluds. The four phytocoenosis types used for display are defined in Table 3; a legend is provided with Fig. 4 .

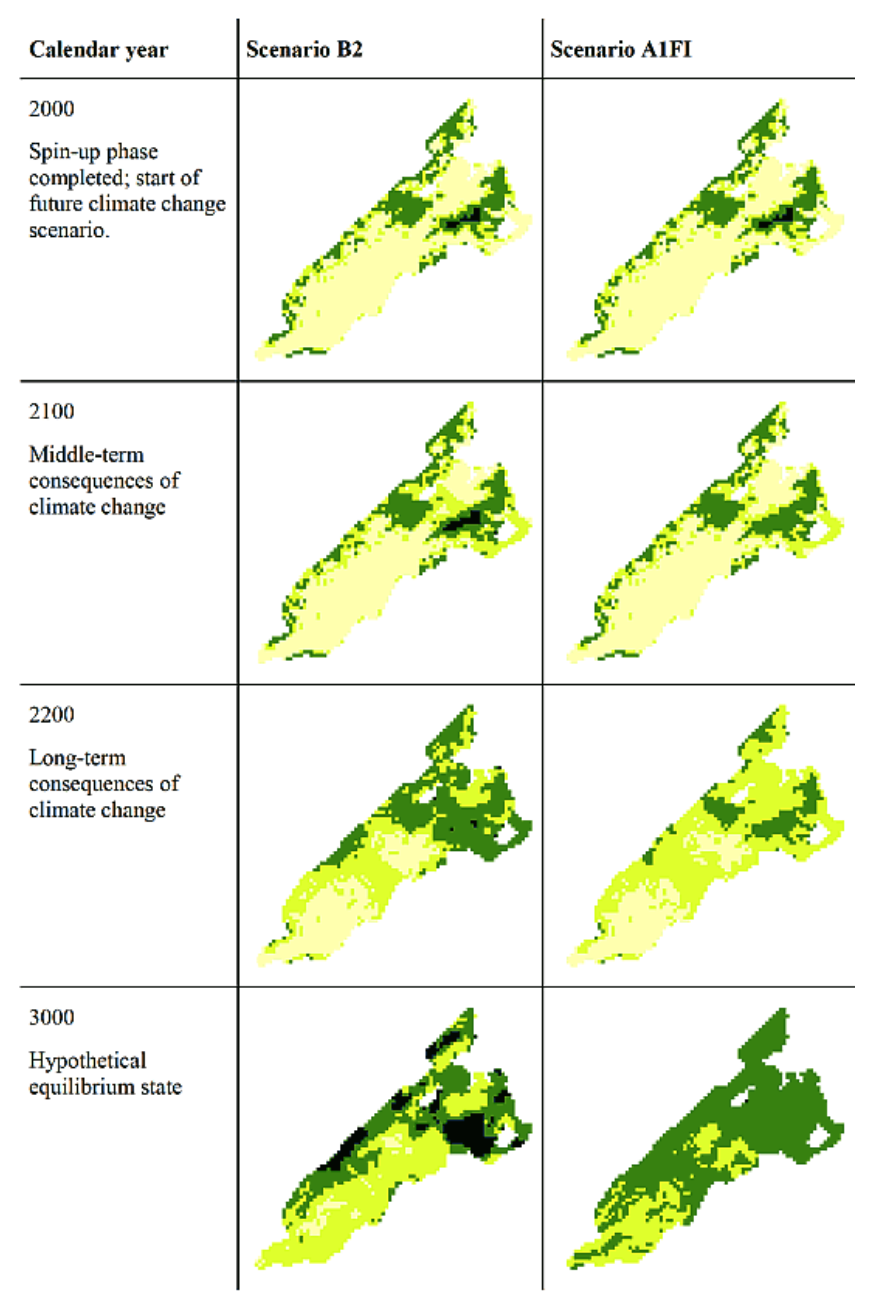

This purely climate-driven dynamic was best expressed in the subalpine pasture Bullatonne, while in the extensively grazed subalpine pasture Pré aux Veaux, at higher elevation geomorphological conditions triggered some initial fluctuations (see the sensitivity analysis in the Appendix for details). In the pasture Planets-Cluds at lower altitude and with high grazing intensity, forest encroachment was much slower, but regressive succession in the scenario A1FI occurred at a similar speed. Here, a comparatively large proportion of unwooded and sparsely wooded pastures was maintained.

Between the years 2100 and 2500, a shift in tree species composition driven by climate change took place, which came 
with a temporary decrease in cover of trees producing high quality wood (Fig. 9). In all scenarios, Norway spruce (Picea abies) declined from around 2100 on, and its decline was accelerated with warming. In the moderate scenario B2, spruce was replaced by beech (Fagus sylvatica) from year 2100 on. However, it took several hundred years before beech reached significant cover at landscape scale because beech is currently hardly present in the landscape, its migration rate is slow, and its establishment is hindered by browsing. The sensitivity of the establishment of beech to stocking densities is shown by the extensively grazed mountain pasture Pré aux Veaux, where beech could reach significant cover quite early. To the contrary, the immigration of beech was slowest in the intense pasture Planets-Cluds. During the temporal gap in the transition from spruce to beech forests, rowan berry (Sorbus aисирагia) as a pioneer tree dominated the landscape. In the extreme warming scenario A1FI, spruce was replaced by Scots pine (Pinus sylvestris) comparatively rapidly due to its high dispersal rate, and rowan berry failed to form a transient phase of forest succession. Interestingly, the cover of pine at the landscape scale shows fluctuations in the long run, which indicates a shifting mosaic cycle. Although the landscape appeared to be dominated by densely wooded pastures in Fig. 7, the cover of pine was only 20-30\% (Fig. 9). In the mountain pastures (Bullatonne and Pré aux Veaux), pine was accompanied by downy oak (Quercus pubescens) and additionally by beech in Pré aux Veaux, where climate is a little cooler because the site is at a higher altitude above sea level.

The landscape structural heterogeneity generally decreased in climate change simulations, as indicated by a higher landscape aggregation index in Fig. 7. Ongoing tree species shift temporarily increased landscape heterogeneity (around 2100 in the moderate scenario B2 due to the spread of rowan berry and around 2300 in the extreme scenario A1FI due to the establishment of pine). In the long run, the segregation of beech forest from sparsely wooded pastures with some open grasslands increased landscape heterogeneity again to some extent in the moderate scenario B2, while in the extreme warming scenario A1FI, the development of homogenous pine forests generally simplified the landscape pattern.

\section{DISCUSSION}

\section{Model performance}

Model refinements as listed in the Appendix allowed for the successful reproduction of natural vegetation and of grazing impacts on tree species composition and landscape structure (results of calibration will be shown in detail in a further paper), which demonstrates the capability of WoodPaM to adequately simulate vegetation zonation along multifactorial gradients of altitude, microclimate, and grazing intensity.
Fig. 9. Tree species shift following climate change in the wooded pastures Planets-Cluds, Bullatonne, and Pré aux Veaux (m a.s.l. $=$ meters above sea level). The pasture Rionde was not simulated for being at the same altitude as Pré aux Veaux. Species not occurring during the simulations are not displayed. Species abbreviations: Pa: Picea abies; Fs: Fagus sylvatica; Ps: Pinus sylvestris; Qh: Quercus pubescens; Sa: Sorbus aucuparia.

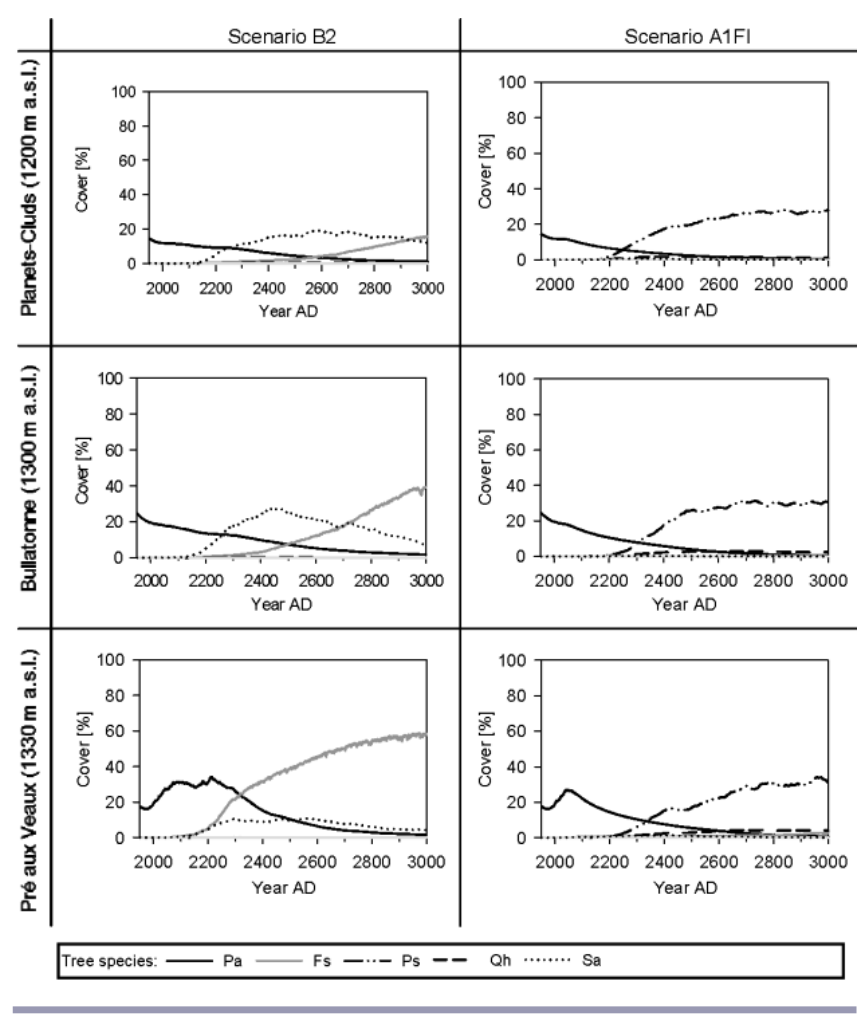

However, two major limitations of the model remain that have to be considered when interpreting the simulation results presented. First, retrospective simulations of the pasture Rionde (near past: 1900-2000) show that logging and windstorms play an important role in shaping landscape patterns and closely interact with simulated successional trends of pattern formation under grazing. Hence, the understanding of historical and future landscape dynamics would profit from the consideration of a further extended multiple disturbance regime, i.e., windstorms and logging in addition to grazing and drought, which both are currently implemented in the model (drought impacts on tree species only). By this means, we would cope with current research needs (Seidl et al. 2011). We recently investigated the role of logging and promoted tree species migration through forest management on landscape structural dynamics from a strategic perspective (Gillet and Peringer 2012) and found that both have the potential to mitigate climate change impacts, 
when carefully applied. In this study, however, we simulated vegetation dynamics driven by grazing alone in order to learn about the importance of logging and windstorms from the poor reproduction of open grassland in the historical analysis.

Furthermore, when interpreting simulation results, the indirect effects of logging have to be kept in mind: logging is the traditional complementary land use in pasture-woodlands, and isolated trees in sparsely wooded pastures have been preferably felled for fire wood for reasons of low effort and improvement of forage production of the pasture. Cattle then focus on such cleared area, which in turn allows the development of dense stands in subsequently neglected areas (rocky sites, slopes, corners of the paddocks). Logging therefore might explain both the general underestimation of forests and the overestimation of sparsely wooded pasture by simulations. To the contrary, windstorms show a homogenizing effect on landscape structure and can wipe out such patterns of grassland-forest segregation (results from the near past in the pasture Rionde).

The second limitation is the overestimation of forage production because we did not consider drought effects on the primary production of grasslands. Drought periods are supposed to heavily impact forage provision in the future (see Gavazov et al. [2013] for a study in which we addressed this issue explicitly). Such an overestimation of productivity promotes forest encroachment because the overall browsing pressure is reduced (Vandenberghe et al. 2007, 2008, 2009). We tried to balance this bias with an assumed slow adaptation of the productivity of the herb layer to the increasing length of the growing season. However, assuming grassland communities to be adapted to the climate of the past 50 years is a rough estimate, which has not been verified yet. The community-based modeling of the herb layer by WoodPaM does not explicitly consider plant species or plant functional groups (as, for example, in the GraS model by Siehoff et al. 2011). Subsequently, a rebuild of new plant grassland communities that form under future climatic conditions cannot be simulated similarly to tree communities in a mechanistic way.

\section{Sensitivity of pasture-woodlands to land use intensity and climate change}

Under stable climatic conditions, grazing pressure and tree cover are negatively correlated: pasture extensification reduces browsing pressure and leads to densification of forested areas and the loss of grassland (Pré aux Veaux and Rionde in the second half of the twentieth century in Fig. 5 [near past], Vandenberghe 2006, Peringer and Rosenthal 2011, Siehoff et al. 2011), whereas intensification suppresses tree regeneration and grasslands emerge. Once established, grasslands persist because they represent the main forage resource for cattle (Planets-Cluds in retrospective simulations of the far past). These processes take a long time under mountainous conditions: diversely structured mosaic pastures emerge very slowly due to self-organization processes under extensive grazing acting over centuries (far past [Olff et al. 1999, Mouissie et al. 2008]) and because regressive succession driven by grazing alone is slow due to the high maximum age and the enduring capability of adult trees (Olff et al. 1999, Van Uytvanck et al. 2008). To the contrary, clear-cuts and windstorms homogenize mosaic patterns very rapidly (near past, pasture Rionde). As long as small patches of woodland remain after such disturbance, however, forest encroachment can be comparatively fast in a window of opportunity of temporary extensification (Pré aux Veaux and Rionde in the second half of the twentieth century in Fig. 5 [near past], Rionde in the period after intense logging during the World War II in Fig. 6 [near past] [Keddy 1992, Allen et al. 2011]).

Slight climate fluctuations, as they happened in the far past (Little Ice Age), trigger forest progression and regression, but to a limited extent: climate cooling of approximately $-1 \mathrm{~K}$ between the Middle Ages and the Little Ice Age (far past) led to a decrease in simulated tree cover and an increase in open grassland over centuries. Generally, reduced forage production increased overall grazing and browsing pressure, weakened tree regeneration, and-over decades and centuries -led to regressive succession. Climate warming of $+1 \mathrm{~K}$ during the twentieth century initiated the opposite effect (Bullatonne, near past). Such tree cover fluctuations align with pollen data from a mire in the Amburnex Valley, where the mountain pastures Pré aux Veaux and Rionde are situated (Sjogren 2005, 2006).

From these interrelationships between grazing and browsing pressure, climate, and tree cover dynamics, one might conclude that enhanced grazing and browsing pressure could be an opportunity to mitigate future climate change impacts, i.e., the simulated forest progression following future climate warming. Increased cattle stocking densities might counteract the projected loss of species-rich mountain grasslands. However, all patterns on which the comparative historical analysis is based share the same general structure and tree species composition of pasture-woodlands, i.e., a mosaic of unwooded pastures and spruce forests connected by ecotones of sparsely and densely wooded pastures. Simulations of future climate change vividly show qualitative and inevitable changes in landscape structure resulting from a shift in tree species triggered by future climate warming, which is far beyond historical temperature fluctuations in both climate change scenarios $(\sim 4 \mathrm{~K}$ in scenario $\mathrm{B} 2$ and $\sim 8 \mathrm{~K}$ in scenario A1FI in contrast to $\sim 1 \mathrm{~K}$ in the near and far past). Moderate warming (B2) forces segregation of the pasture-mosaic into grazed forest and sparsely wooded pasture or grassland. Densely wooded pastures widely disappear. Landscape diversity and related biodiversity subsequently decrease. Extreme warming homogenizes the landscape pattern to an 
almost uniform distribution of densely wooded pastures. Even though densely wooded pastures imply a high structural diversity in themselves because they represent the structure of semi-open landscapes in a fine-grained way, biodiversity will lack species that require large patches of open grassland or closed forest (Lederbogen et al. 2004).

The processes behind the formation of these patterns are (1) the drought-induced collapse of currently dominating stands of spruce and (2) its slow replacement by beech following moderate warming or by Scots pine with some downy oak following extreme warming. After moderate warming of $\sim 4$ $\mathrm{K}$, temperature levels in the Jura Mountains correspond to current lowland conditions $(500 \mathrm{~m}$ a.s.l., assuming an elevation lapse rate of $0.5 \mathrm{~K}$ per $100 \mathrm{~m}$ in altitude), where beech is frequently dominant today. After extreme warming $(\sim 8 \mathrm{~K})$, temperatures correspond to current sea level (e.g., La Rochelle in France at similar latitude), where pine and downy oak are currently found.

Climatic determinants of landscape structure differ between the past and the future: for the past, we found temperature was most influential, while in the future, we expect drought stress on the karstic Jura Mountains to select dominant tree species from the species pool. Although the yearly sum of precipitation is not expected to change significantly in the future (Fig. 3), seasonality and return frequencies of summer droughts are (Calanca 2007). Especially, summer droughts are causal for the decline of spruce and for the dominance of pine after extreme warming. Landscape structure changes according to the ecology of new tree species: landscape segregation in the scenario $\mathrm{B} 2$ is driven by the ability of beech to regenerate well in the shade of old stands, which are avoided by cattle (Smit et al. 2005) and where browsing intensity and drought stress is lower in comparison to sparsely wooded pasture or grassland. Landscape homogenization in the scenario A1FI is driven by the establishment of pine on grassland, where the high light requirements of pine seedlings for establishment are satisfied exclusively. The lack of pine regeneration in old stands is also the reason for shifting mosaic cycles that might appear in pine-dominated pasture-woodlands, as suggested by our simulations. In the very long run, such light pine forests might transform into forests of downy oak, as indicated in our simulations (Fig. 9) and recent studies in the Valais (Huber et al. 2013).

\section{Implications for ecosystem services and management}

Pasture-woodlands depend on a balance between the (natural) successional trend towards forest development and the oppression of tree establishment by browsing. Our simulations underpin the observed sensitivity of pasture-woodlands to land use change (Chételat et al. 2013) and provide a mechanistic explanation for climate change impacts. Most important, climate change scenarios demonstrate that future climate will cause qualitative shifts in the landscape mosaic regardless of grazing pressure (Huber et al. 2013). Although simulations of future climate do not predict immediate landscape structural changes of similar speed and magnitude as observed after recent extensification during the last century, this does not mean that pasture-woodlands are resistant to climate change. To the contrary, shifts in landscape structure, tree species composition, and thus ecosystem service provision are predicted to occur even more rapidly and drastically than known from the past after a delay of approximately 50 years.

Especially, the decline of spruce is probably underestimated in the model because we considered neither windstorms (which are supposed to occur more frequently in the future [Matulla et al. 2008, Swiss Climate Change Scenarios 2011]), nor bark beetle outbreaks. Outbreaks are known to be triggered by windstorms and drought (Schlyter et al. 2006), and trees are more susceptible to bark beetle attack under drought stress (Wermelinger 2004). Considering the current scarcity of beech and pine in the neighborhood of the pastures, the establishment rate of both species is probably overestimated. Both model uncertainties increase the probability of simulated forest breakdown in climate change scenarios. The temporal "gap" in the provision of the ecosystem service "quality wood production" might happen to an even larger extent than simulated. The promotion of beech establishment by forest management, however, has the potential to mitigate this effect (Gillet and Peringer 2012).

Regarding the ecosystem service "forage production," seasonal scarcity of water, as indicated by the dominance of pine following extreme warming, will reduce grassland productivity in the future and demand a reduction in cattle stocking or an innovative management scheme (cisterns capturing snow melt water, adapted breeds). While stocking rate will need to be reduced in open and nowadays intensively used pastures exposed to summer drought and subsequently collapse of herb layer productivity (Gavazov et al. 2013), it will become crucial to enhance stocking rates in more encroached areas in order to maintain a diverse pasturewoodland mosaic in the light of climate change. The biodiversity of pasture-woodlands strongly depends on landscape structures (mosaics and interconnecting ecotones), which emerge exclusively from extensive grazing (Lederbogen et al. 2004, Peringer and Rosenthal 2009, Rosenthal et al. 2012). Direct human intervention (logging, shrub cutting) can maintain open grassland. Species-rich forest-grassland ecotones, however, are usually destroyed by pasture clearing. The segregation between grassland and forest, which is predicted for moderate climate warming, comes with a drastic loss of open pastures and their ecotones to forest. Both can be mitigated with enhanced browsing pressure. Because enhanced cattle stocking can also lead to soil compaction, and root and stem damage in forest, various grazers and browsers might provide an opportunity to promote 
regressive succession and avoid such negative effects (Jorritsma et al. 1999, Vera, 2000). While the historical landscape dynamics in Planets-Cluds (far past) show that segregation is not reversed but promoted by intense cattle grazing, browsing animals are able to thin forests to densely wooded pastures and clear sparsely wooded pasture to open grassland. Thus, we argue for (1) extended stocking periods adapted to enlarged future vegetation periods, and (2) the (re-) introduction of horses, sheep, and goats. The differences in forage selectivity between these herbivores and cattle would counteract fallow succession of grassland (especially, horses graze where cattle do not) and tree encroachment (browsing by sheep and goats) (Rook et al. 2004, Rosenthal et al. 2012). Both constitute an opportunity to maintain the desired heterogeneous landscapes with their biodiversity, which indeed calls for reforms in policies (Huber et al. 2013). However, considering the known sensitivity of Mediterranean pine forests to devastation by overgrazing (González-Martínez and Bravo 2001) and keeping in mind that real temperature increase most probably will be in between the two simulated scenarios, intensification of stocking should be done carefully in order to not hinder the immigration of new tree species, especially browsing-sensitive beech.

If stocking turns out to be generally limited due to future seasonal scarcity of water or socioeconomic constraints, forest management becomes more important for shaping landscape structure. Though, logging should support mosaic and ecotone structures, which again would need reforms in policies (Huber et al. 2013). Selective felling of single trees instead of large clear-cuts, however, can have contrasting effects depending on the forest type: while in pine forests, which emerged following extreme warming, landscape structure can be diversified, the mosaic of beech forest and grassland, which developed following moderate warming, can be simplified into a more homogenous landscape (Gillet and Peringer 2012).

In summary, our results clearly show that inevitable shifts in landscape structure have to be expected due to climate change. Adapted land use, however, offers opportunities to mitigate climate change impacts on pasture-woodlands. Policy development should focus on the provision of favorable socioeconomic conditions for the future practice of diverse livestock breeding in mountain pastures in combination with careful logging with respect to forest-grassland ecotones.

Responses to this article can be read online at: http://www.ecologyandsociety.org/issues/responses. php/5600

\section{Acknowledgments:}

This work was supported by the CCES (Competence Center Environment and Sustainability of the ETH Domain, Switzerland) as part of the MOUNTLAND project and by the State Secretariat for Education and Research (SER C07.0112) in the framework of the COST Action FP0603. We also thank Konstantin Gavazov, Andreas Rigling, Rober Huber, Kathryn Lannas, Jean-Bruno Wettstein, and Michael Kalbermatten.

\section{LITERATURE CITED}

Allen, V. G., C. Batello, E. J. Berretta, J. Hodgson, M. Kothmann, X. Li, J. McIvor, J. Milne, C. Morris, A. Peeters, and M. Sanderson. 2011. An international terminology for grazing lands and grazing animals. Grass and Forage Science 66:2-28.

Béguin, D. 2007. Tree regeneration and growth in wood pastures: patterns and processes. Dissertation. University of Neuchâtel, Neuchâtel, Switzerland.

Brandt, J. 2003. Multifunctional landscapes—perspectives for the future. Journal of Environmental Sciences-China 15:187192.

Buttler, A., F. Kohler, and F. Gillet. 2009. The Swiss mountain wooded pastures: patterns and processes. Pages 377-396 in A. Rigueiro-Rodriguez, J. McAdam, and M. R. MosqueraLosada, editors. Agroforestry in Europe: current status and future prospects. Springer, New York. http://dx.doi. org/10.1007/978-1-4020-8272-6 19

Calanca, P. 2007. Climate change and drought occurrence in the Alpine region: How severe are becoming the extremes? Global and Planetary Change 57:151-160. http://dx.doi.org/ http://dx.doi.org/10.1016/j.gloplacha.2006.11.001

Chételat, J., M. Kalbermatten, K. Lannas, A. Buttler, J. B. Wettstein, F. Gillet, A. Peringer, and T. Spiegelberger. 2013. A contextual analysis of observed land-use and vegetation changes applied to two wooded pastures in the Swiss Jura Mountains. This feature.

Dufour, A., F. Gadallah, H. H. Wagner, A. Guisan, and A. Buttler. 2006. Plant species richness and environmental heterogeneity in a mountain landscape: effects of variability and spatial configuration. Ecography 29:573-584. http://dx. doi.org/10.1111/j.0906-7590.2006.04605.x

Etienne, M., editor. 1996. Western European silvopastoral systems. INRA Editions, Paris, France.

Federal Office for Agriculture (FOAG). 1972. Land Register for Agricultural Production. Bern, Switzerland. 
Federal Office for Agriculture (FOAG). 1974. Land Register for Mountain Agriculture. Bern, Switzerland.

Gallandat, J.-D., F. Gillet, E. Havlicek, and A. Perrenoud 1995. Typologie et systémique phyto-écologiques des pâturages boisés du Jura Suisse. Laboratoire d'écologie végétale, Neuchâtel, Université de Neuchâtel, Switzerland.

Gavazov, K., A. Peringer, F. Gillet, S. Siehoff, A. Buttler, and T. Spiegelberger. 2013. Dynamics of forage production in pasture-woodlands of the Swiss Jura Mountains under projected climate change scenarios. Ecology and Society 18 (1):38. http://dx.doi.org/10.5751/ES-04974-180138

Gillet, F. 2008. Modelling vegetation dynamics in heterogeneous pasture-woodland landscapes. Ecological Modelling 217:1-18. http://dx.doi.org/10.1016/j.

ecolmodel.2008.05.013

Gillet, F., O. Besson, and J.-M. Gobat. 2002. PATUMOD: a compartment model of vegetation dynamics in wooded pastures. Ecological Modelling 147:267-290. http://dx.doi. org/10.1016/S0304-3800(01)00427-6

Gillet, F., and J.-D. Gallandat. 1996. Wooded pastures of the Jura Mountains. Pages 37-53 in M. Etienne, editor. Western European silvopastoral systems. INRA Editions, Paris, France.

Gillet, F., B. Murisier, A. Buttler, J.-D. Gallandat, and J.-M. Gobat. 1999. Influence of tree cover on the diversity of herbaceous communities in subalpine wooded pastures. Applied Vegetation Science 2:47-54. http://dx.doi. org/10.2307/1478880

Gillet, F., and A. Peringer. 2012. Dynamic modelling of silvopastoral landscape structure: scenarios for future climate and land use. Pages 860-867 in R. Seppelt, A. A. Voinov, S. Lange, and D. Bankamp, editors. International Environmental Modelling and Software Society (iEMSs) 2012 International Congress on Environmental Modelling and Software. Managing Resources of a Limited Planet: Pathways and Visions under Uncertainty, Sixth Biennial Meeting, Leipzig, Germany. [online] URL: http://www.iemss.org/sites/iemss2012/ proceedings.html

González-Martínez, S. C., and F. Bravo. 2001. Density and population structure of the natural regeneration of Scots pine (Pinus sylvestris L.) in the High Ebro Basin (Northern Spain). Annals of Forest Science 58:277-288. http://dx.doi. org/10.1051/forest:2001126

He, H. S., and D. J. Mladenoff. 1999. Spatially explicit and stochastic simulation of forest-landscape fire disturbance and succession. Ecology 80(1):81-99. [online] URL: http://www. jstor.org/stable/176981

Huber, R., S. Briner, A. Peringer, S. Lauber, R. Seidl, A. Widmer, F. Gillet, A. Buttler, Q. Bao Le, and C. Hirschi. 2013.
Modeling social-ecological feedback effects in the implementation of payments for environmental services in pasture-woodlands. Ecology and Society 18(2): 41. http://dx. doi.org/10.5751/ES-05487-180241

Intergovernmental Panel on Climate Change (IPCC). 2000. Emissions scenarios-summary for policymakers. A Special Report of IPCC Working Group III.

Jorritsma, I. T. M., A. F. M. Van Hees, and G. M. J. Mohren. 1999. Forest development in relation to ungulate grazing: a modeling approach. Forest Ecology and Management 120:2334. http://dx.doi.org/10.1016/S0378-1127(98)00540-4

Keddy, P. A. 1992. Assembly and response rules: two goals for predictive community ecology. Journal of Vegetation Science 3:157-164. http://dx.doi.org/10.2307/3235676

Kleyer, M., R. Biedermann, K. Henle, E. Obermaier, H.-J. Poethke, P. Poschlod, B. Schröder, J. Settele, and D. Vetterlein. 2007. Mosaic cycles in agricultural landscapes of Northwest Europe. Basic and Applied Ecology 8:295-309. http://dx.doi.org/10.1016/j.baae.2007.02.002

Kohler, F., F. Gillet, S. Reust, H. H. Wagner, F. Gadallah, J. M. Gobat, and A. Buttler. 2006. Spatial and seasonal patterns of cattle habitat use in a mountain wooded pasture. Landscape Ecology 21:281-295. http://dx.doi.org/10.1007/s10980-005-0144-7

Lederbogen, D., G. Rosenthal, D. Scholle, J. Trautner, B. Zimmermann, and G. Kaule. 2004. Allmendweiden in Südbayern: Naturschutz durch landwirtschaftliche Nutzung. In Bundesamt für Naturschutz, editor. Reihe für Angewandte Landschaftsökologie 62. Bonn, Germany.

Leeuw, S. v. d., R. Costanza, S. Aulenbach, S. Brewer, M. Burek, S. Cornell, C. Crumley, J. A. Dearing, C. Downy, L. J. Graumlich, S. Heckbert, M. Hegmon, K. Hibbard, S. T. Jackson, I. Kubiszewski, P. Sinclair, S. Sörlin, and W. Steffen. 2011. Toward an integrated history to guide the future. Ecology and Society 16(4):2. [online] URL: http://www. ecologyandsociety.org/vol16/iss4/art2/

Matulla, C., W. Schöner, H. Alexandersson, H. von Storch, and X. L. Wang. 2008. European storminess: late nineteenth century to present. Climate Dynamics 31:125-130. http://dx. doi.org/10.1007/s00382-007-0333-y

Max Planck Institute for Meteorology (MPI-M). 2006. Climate data. Hamburg, Germany.

Max Planck Institute for Meteorology (MPI-M). 2009. Climate data. Hamburg, Germany.

Moberg, A., D. M. Sonechkin, K. Holmgren, N. M. Datsenko, and W. Karlen. 2005. Highly variable Northern Hemisphere temperatures reconstructed from low- and high-resolution proxy data. Nature 433:613-617. http://dx.doi.org/10.1038/ $\underline{\text { nature } 03265}$ 
Mosquera-Losada, M. R., A. Riguerio, and J. McAdam. 2005. Silvopastoralism and sustainable land management. CABI, Wallingford, UK.

Mouissie, A. M., M. E. F. Apol, G. W. Heil, and R. van Diggelen. 2008. Creation and preservation of vegetation patterns by grazing. Ecological Modelling 218:60-72. http:// dx.doi.org/10.1016/j.ecolmodel.2008.06.018

Olff, H., and M. E. Ritchie. 1998. Effects of herbivores on grassland plant diversity. Trends in Ecology \& Evolution 13:261-265. http://dx.doi.org/10.1016/S0169-5347(98)01364-0

Olff, H., F. W. M. Vera, J. Bokdam, E. S. Bakker, J. M. Gleichman, K. de Maeyer, and R. Smit. 1999. Shifting mosaics in grazed woodlands driven by the alternation of plant facilitation and competition. Plant Biology 1:127-137. http:// dx.doi.org/10.1111/j.1438-8677.1999.tb00236.x

Peringer, A., and G. Rosenthal. 2011. Establishment patterns in a secondary tree line ecotone. Ecological Modelling 222:3120-3131. http://dx.doi.org/10.1016/j.ecolmodel.2011.05.025

Peringer, A., and G. Rosenthal. 2009. Raum-Zeitmuster der Gehölzsukzession in Kalkflachmooren. Naturschutz und Landschaftsplanung 41:173-180.

Perrenoud, A., U. Känzig-Schoch, O. Schneider, and J.-B. Wettstein. 2003. Exploitation durable des pâturages boisés: un exemple appliqué du Jura Suisse - Nachhaltige Bewirtschaftung von Wytweiden: ein Beispiel aus dem Schweizer Jura. Haupt, Bern, Stuttgart, Wien.

Poschlod, P., J. P. Bakker, and S. Kahmen. 2005. Changing land use and its impact on biodiversity. Basic and Applied Ecology 6:93-98. http://dx.doi.org/10.1016/j.baae.2004.12.001

Rook, A. J., B. Dumont, J. Isselstein, K. Osoro, M. F. WallisDeVries, G. Parente, and J. Mills. 2004. Matching type of livestock to desired biodiversity outcomes in pastures-a review. Biological Conservation 119:137-150. http://dx.doi. org/10.1016/j.biocon.2003.11.010

Rosenthal, G., J. Schrautzer, and C. Eichberg 2012: Low intensity grazing with domestic herbivores: a tool for maintaining and restoring plant diversity in temperate Europe. Tuexenia 32:167-205.

Schlyter, P., I. Stjernquist, L. Bärring, A. M. Jönsson, and C. Nilsson. 2006. Assessment of the impacts of climate change and weather extremes on boreal forests in northern Europe, focusing on Norway spruce. Climate Research 31:75-84. http://dx.doi.org/10.3354/cr031075

Schumacher, S., and H. Bugmann. 2006. The relative importance of climatic effects, wildfires and management for future forest landscape dynamics in the Swiss Alps. Global Change Biology 12:1435-1450. http://dx.doi.org/10.1111/ j.1365-2486.2006.01188.x
Schumacher, S., H. Bugmann, and D. J. Mladenoff. 2004. Improving the formulation of tree growth and succession in a spatially explicit landscape model. Ecological Modelling 180:175-194. http://dx.doi.org/10.1016/j.ecolmodel.2003.12.055

Schumacher, S., B. Reineking, J. Sibold, and H. Bugmann. 2006. Modeling the impact of climate and vegetation on fire regimes in mountain landscapes. Landscape Ecology 21:539 554. http://dx.doi.org/10.1007/s10980-005-2165-7

Seidl, R., P. M. Fernandes, T. F. Fonseca, F. Gillet, A. M. Jonsson, K. Merganicova, S. Netherer, A. Arpaci, J. D. Bontemps, H. Bugmann, J. R. Gonzalez-Olabarria, P. Lasch, C. Meredieu, F. Moreira, M. J. Schelhaas, and F. Mohren. 2011. Modelling natural disturbances in forest ecosystems: a review. Ecological Modelling 222:903-924. http://dx.doi. org/10.1016/j.ecolmodel.2010.09.040

Siehoff, S., G. Lennartz, I. C. Heilburg, M. Roß-Nickoll, H. T. Ratte, and T. G. Preuss. 2011. Process-based modeling of grassland dynamics built on ecological indicator values for land use. Ecological Modelling 222:3854-3868. http://dx.doi. org/10.1016/j.ecolmodel.2011.10.003

Sjogren, P. J. E. 2005. Palaeoecological investigations of pasture woodland in Combe des Amburnex, Swiss Jura Mountains. Dissertation. Universität Bern, Bern, Switzerland.

Sjogren, P. 2006. The development of pasture woodland in the southwest Swiss Jura Mountains over 2000 years, based on three adjacent peat profiles. Holocene 16:210-223. http:// dx.doi.org/10.1191/0959683606h1921rp

Smit, C., D. Beguin, A. Buttler, and H. Muller-Scharer. 2005. Safe sites for tree regeneration in wooded pastures: a case of associational resistance? Journal of Vegetation Science 16:209-214. http://dx.doi.org/http://dx.doi.org/10.1111/ j.1654-1103.2005.tb02357.x

Svenning, J. C. 2002. A review of natural vegetation openness in north-western Europe. Biological Conservation 104:133148. http://dx.doi.org/10.1016/S0006-3207(01)00162-8

Swetnam, T. W., C. D. Allen, and J. L. Betancourt. 1999. Applied historical ecology: using the past to manage for the future. Ecological Applications 9:1189-1206. http://dx.doi. org/10.1890/1051-0761(1999)009[1189:AHEUTP]2.0.CO;2

Swiss Climate Change Scenarios 2011 (CH2011). Publ. by C2SM, MeteoSwiss, ETH, NCCR Climate, and OcCC. Zurich, Switzerland.

van Lier, H. N. 1998. The role of land use planning in sustainable rural systems. Landscape and Urban Planning 41:83-91. http://dx.doi.org/10.1016/S0169-2046(97)00061-3

Van Uytvanck, J., D. Maes, D. Vandenhaute, and M. Hoffmann. 2008. Restoration of woodpasture on former agricultural land: the importance of safe sites and time gaps 
before grazing for tree seedlings. Biological Conservation 141:78-88. http://dx.doi.org/10.1016/j.biocon.2007.09.001

Vandenberghe, C. 2006. The influence of cattle activity on tree regeneration in wood-pastures. Dissertation. École Polytechnique Fédérale de Lausanne, Lausanne, Switzerland.

Vandenberghe, C., F. Freléchoux, and A. Buttler. 2008. The influence of competition from herbaceous vegetation and shade on simulated browsing tolerance of coniferous and deciduous saplings. Oikos 117:415-423. http://dx.doi. org/10.1111/j.2007.0030-1299.16264.X

Vandenberghe, C., F. Freléchoux, M. A. Moravie, F. Gadallah, and A. Buttler. 2007. Short-term effects of cattle browsing on tree sapling growth in mountain wooded pastures. Plant Ecology 188:253-264. http://dx.doi.org/10.1007/s11258-006-9160-1

Vandenberghe, C., C. Smit, M. Pohl, A. Buttler, and F. Freléchoux. 2009. Does the strength of facilitation by nurse shrubs depend on grazing resistance of tree saplings? Basic and Applied Ecology 10:427-436.

Vera, F. W. M. 2000. Grazing ecology and forest history. CAB International, Oxford, UK.

Wermelinger, B. 2004. Ecology and management of the spruce bark beetle Ips typographus - a review of recent research. Forest Ecology and Management 202:67-82. http://dx.doi. org/10.1016/j.foreco.2004.07.018 


\title{
Past and future landscape dynamics in wooded pastures of the Jura Mountains under land-use and climate change
}

\begin{abstract}
APPENDIX
This document provides detailed information about improvements of the model WoodPaM made for the simulations presented in the manuscript. With the exception of the sensitivity analysis at the end of the appendix, it is similarly structured to the model description in Gillet (2008). However, only refinements to this earlier model version are stated here.
\end{abstract}

\section{METHODS}

\section{The herb submodel}

\section{Succession}

In succession from fallow to understory, a lightfleck- and an edge-effect are implemented that both restrict the transformation from fallow F to understory U (flow FtoU in Gillet (2008), Equation A1). Subsequently, the cover of fallow in forest is enhanced and stand regeneration facilitated, because on fallows tree recruitment is not reduced by shading (see modifications in the tree submodel). This modification is based on our observations of the light climate and the herb layer in uneven-aged forest stands, which are characteristic in wood-pastures.

$$
\text { FtoU }=\left(\text { TreeCover }{ }^{*} \mathrm{~F}\right)-(\mathrm{U} *(\mathrm{~F}+0.01+0.1 *(1-\text { TreeCover })))
$$

[Equation A1]

The development of fallow from eutrophic pasture is made independent to dunging intensity in order to accelerate fallow succession. With the original formulation an unrealistic slow transformation of eutrophic pastures into fallows occurred in experimental simulations of abandonment, while lawns transformed into fallow much faster. Our modification assumes fallow succession to be faster under eutrophic conditions.

Fallow succession is considered to be accelerated by climate warming on both, eutrophic pastures and lawns. Thus, the altitude effect $\mathrm{AE}$ is added as a multiplier to the transformation flux from eutrophic pastures M to fallow F (MtoF, Gillet (2008)), while in the transformation flux of lawn to fallow (LtoF) climate warming was already considered.

\section{Forage production}

Yearly local forage production in a grid cell (LFP) is computed based on a new regression model (in comparison to Gillet 2008). The model relates empirical data on productivity from the same set of vegetation surveys from the Jura Mountains and the Alps as used in Gillet (2008) to the local pastoral value LPV and (newly) to the length of the growing season vegdays (Equation A2). LPV is a function of the successional state of the herb layer in a grid cell (cover of the four ecological community types: eutrophic pastureland $\mathrm{M}$, oligotrophic pastureland $\mathrm{L}$, fallow $\mathrm{F}$ and understory $\mathrm{U}$ ). Most important, vegdays is not only calculated from the current year, but from the average temperature of the last 50 years, dynamically 
looking back from each simulation year (see section climate submodel). By this means, we take into account that the productivity of grassland plant communities increases slowly following the general trend of temperature rise due to community adaptation, rather than spontaneously in single warm years.

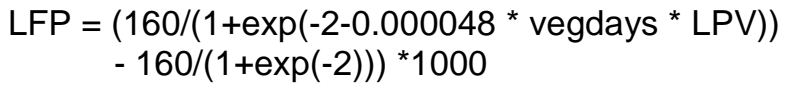

[Equation A2]

Coefficient of determination $\left(R^{2}\right): 0.8 .12$

Vegdays: Length of the vegetation period during the last 50 years [days]

LPV: Local pastoral value of the herb layer in a grid cell

\section{The wood submodel}

\section{Shrubs}

We removed the temporal delay of 5 years in shrub recruitment, because during testing of the original formulation of the model an unrealistic recruitment pattern of shrubs was simulated: Initially, low shrub cover first disappeared and after 5 years shrubs recruited numerously.

\section{Trees}

Based on the species traits available from the forest landscape model LandClim (Bugmann 1994, Schumacher 2004, Schumacher and Bugmann 2006), we implemented a total number of 13 tree species into the tree submodel of WoodPaM (see Table A1). The species pool reflects species composition of current forests in the subalpine belt of the Jura (Norway spruce Picea abies, beech Fagus sylvatica, fir Abies alba, maple Acer pseudoplatanus, Rowan berry Sorbus aucuparia), as well as species currently occurring at lower altitude (e.g. ash Fraxinus excelsior and oaks Quercus spec.). The latter might potentially enter the subalpine belt with projected climate warming and thus are important for consistent simulations of climate change scenarios.

We split the former life stage "tree" into two life stages in order to distinguish mature trees from young trees that do not yet produce seeds but already escaped browsing in the sapling stage. A total number of four life stages of trees (seedlings, saplings, young and adult trees) leads to a more realistic speed of recruitment of trees, because seed producing trees are less numerous. Transition rates from the sapling stage to the young-tree layer and the mature-tree layer are modified in a feasible manner considering tree growth under optimal conditions (minimum transit time in a stage) and under stress from shading (maximum transit time, see Table A1). Total tree cover is calculated from both, the cover of old and of young trees. By this means, all tree individuals taller than 5 meters are considered for habitat use of cattle, for shading of saplings and seedlings and are the determinant for the cover of understory. 
We consider shading by shrubs additionally to shading by trees in the mortality of tree seedlings (flow exTh) and in seedlings' growth (flow ThtoTs). Both flows are calculated as follows (Equation A3):

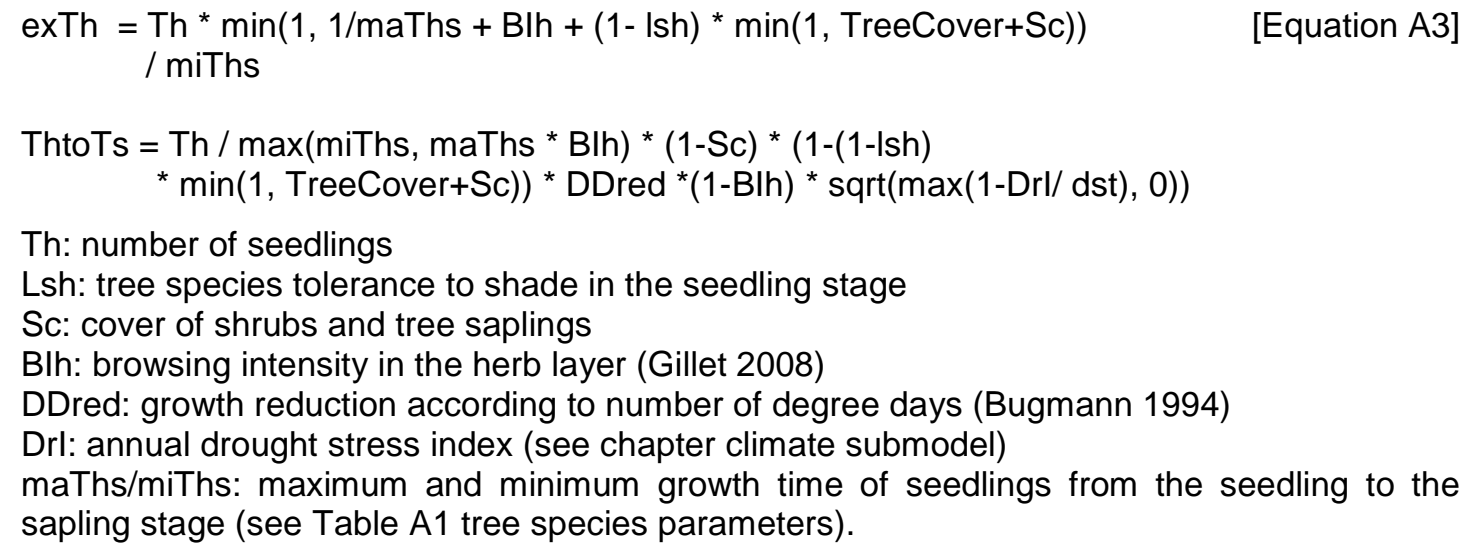

We restrict the establishment of trees in the forest understory and on rock outcrops. In the modified establishment filter, the cover of understory is multiplied with the species specific tolerance to shade lsh (see Table A1), which favors shade tolerant species in closed forests (Equation A4). Establishment on rock is restricted in case of large rock outcrops (Equation A4), because rock face itself does not provide safe sites, only cracks in the rock face and the general bumpy terrain surface does (Béguin 2007).

The climatic restrictions of tree establishment (see chapter climate submodel and Table A1) structurally follow the LandClim forest model. Establishment fails if one of the following conditions is met: The annual drought index DrI exceeds the species specific threshold dst (see Table A1); the annual minimum winter temperature is below the species specific threshold miWT; the annual number of degree days DDS is not within the species specific interval ]miDD, maDD[ (Equation A4).

Resuming such dependencies of establishment of trees on the state of the herb layer and climatic conditions, rejuvenation (number of seedlings inTh) of a tree species is computed as follows (Equation A4):

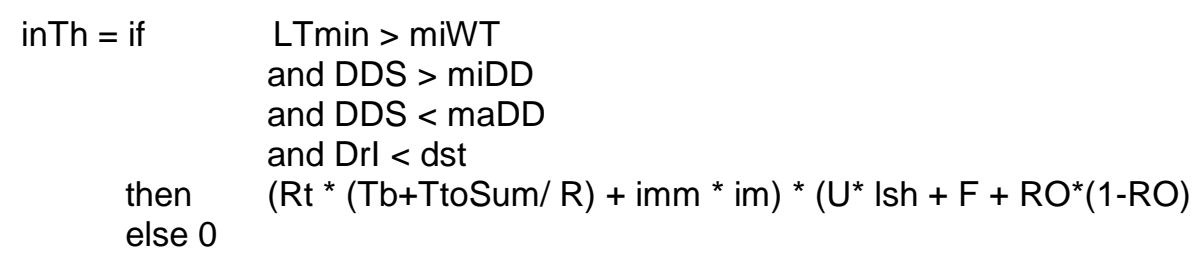

R: number of seedlings from adult trees inside the cell ( $25 \mathrm{~m}$ times $25 \mathrm{~m}$ )

TtoSum: number of trees in the neighboring cells

Rt: modifier of neighborhood seedling recruitment (Gillet 2008)

Im: flag for immigration from outside landscape

Imm: number of seedlings immigrating from outside landscape (arbitrarily set to 0.001 in order to hinder the complete extinction of tree species during simulation, see also Table A1 tree species parameters. 
The parameters of tree species' sensitivity to climate used in LandClim reflect tree species behavior in central alpine climate. We let these values for most tree species unchanged, however, we adjust the behavior of spruce, beech and maple to its behavior in the oceanic climate of the Jura (see Table A1). We changed the following parameters, which Rickebusch et al. (2007) found to control tree species distributions at tree line ecotones:

Minimum number of degree days (miDD) of beech and maple: $\mathrm{miDD}(\mathrm{beech})$ and miDD(maple) are set to 514, which equals minimum number of degree days at $1600 \mathrm{~m}$ a.s.l., being the altitude of the tree line in the Jura. By this means, we allow beech and maple to grow up to observed altitudes (tree line).

Monthly minimum winter temperature (miWT) for establishment and seedlings' mortality (maThs) of spruce: miWT(spruce) is set to $-3.9^{\circ} \mathrm{C}$, which equals miWT(1600 m a.s.1.), being the altitude of the tree line (long term annual minima based on 1901-2000 observations) and seedlings' mortality is enhanced (maThs set to 12.5 instead of 25), which both mimics the limited establishment of spruce in the oceanic subalpine zone with long-lasting snow cover. Here snow fungi infect seedlings and reduce establishment success and competitive strength of spruce (Ellenberg 1996). The minimum number of degree days of spruce remained unchanged, because thick snow limits establishment (regulated by miWT and maThs) and not growth of adult trees (regulated by number of degree days).

We also adjusted the parameters of pine in order to not appear above $1000 \mathrm{~m}$ a.s.l., but on lower altitudes, which fits (personal) observations:

Maximum number of degree days (maDD) of pine: maDD(pine) is set to 4500 as an intermediate between maple (4491) and Quercus robur (4655).

Minimum number of degree days (miDD) of pine: $\mathrm{miDD}$ (pine) is set to 1094 , which equals $\operatorname{miDD}(1000 \mathrm{~m}$ a.s.1.).

The growth parameters of maple were adjusted to emphasize its behavior as a gap species in beech forests:

seedlings' mortality (maThs), saplings' mortality (maTst) and young trees' mortality (maTtb) of maple has been enhanced by halving the former values $(8,40,40)$ to 4,20 and 20.

\section{The climate submodel}

The climate submodel basically computes several annual climate parameters from monthly values for temperature and precipitation, which influence herb layer dynamics, tree establishment and growth: Annual sum of degree days, minimum temperature in winter, yearly average drought stress index and apparent altitude. The latter expresses climate warming through reduced elevation, which accelerates herb layer succession and enhances its productivity (Gillet 2008). For each grid cell, these global parameters are calculated according to its topographic situation (altitude, slope, aspect). 
In general, the structure of the climate submodel follows LandClim (Bugmann 1994, Schumacher 2004), which provides well elaborated formulas for tree species response to temperature and precipitation together with the necessary parameters for all relevant species. However, we substituted equations for the computation of potential evapotranspiration PET and actual evapotranspiration of trees AET with a different approach. We lack detailed data on soil depth in the Jura mountains, where soil conditions vary distinctly at the scale of meters: Rock outcrops and steep slopes carry shallow soils, while Loess deposits even enhance the depth of colluvial soils in depressions (Martignier et al. submitted). Instead of directly estimating soil depth, which is a requisite for the computation of the local water balance and the soil water storage following LandClim, we estimate AET using an equation from hydrological science (Zhang et al. 2001) and apply an empirical modifier of AET proportional to the presence of rock outcrops in a grid cell (for the estimation of rock outcrops refer to Peringer et al., in prep). For the calculation of PET, we choose the Turc-Pike formula (Pike 1964) instead of the Thorntwaite formula originally used in LandClim, because it performs better in combination with the AET calculation of Zhang et al. (2001), leading to reasonable values of drought stress (see sensitivity analysis at the end of the appendix). The climate parameters influencing vegetation dynamics are computed as follows:

Local temperature $L T$ and $L T^{\prime}$ : Due to altitude, slope and aspect, the local temperature in grid cells varies following the geomorphological conditions. First, the current monthly temperature Tvar, which is derived from the climate time series, is adjusted to the altitude A of a cell applying the month-specific elevation lapse rate ELR. Adjusted local temperature LT is calculated as follows (Equation A5):

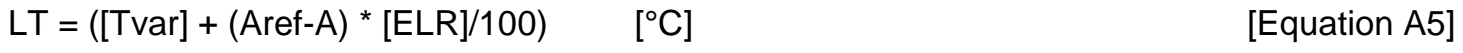

Aref: altitude of the reference climate station [m a.s.I.]

ELR: month-specific elevation lapse rate of temperature $[\mathrm{K} / 100 \mathrm{~m}]$

Second, LT is modified applying the correction factor kpMod for PET from LandClim (Schumacher 2004). This results in the local temperature LT', which reflects the temperature to depend on slope and aspect (Equation A6):

$$
L T^{\prime}=L T^{*}{ }^{*} \mathrm{kpMod} \quad\left[{ }^{\circ} \mathrm{C}\right]
$$

[Equation A6]

Bugmann (1994) derives the kpMod-correction for PET in an empirical way relating the variation of radiation with slope and aspect to measured variability in PET. Thus, kpMod is designed to vary between 1.25 and 0.875 . Direct estimates of temperature dependency on slope-aspect would require a local energy-balance, because cooling effects from AET have a big influence. We base our application of kpMod to estimate local temperature on the fact that PET is coupled to temperature and both depend on the same driver (radiation).

While PET is calculated from LT (following LandClim, where kpMod is applied afterwards to correct for slope-aspect influence), the local number of degree days and minimum winter temperature are calculated from LT'. Thus, in WoodPaM local annual number of degree days and minimum winter temperature vary with microclimatic diversity induced by slope and aspect. This is a requisite to reproduce the complex of Aceri-Fagetum and spruce-rowan berry-community at the treeline, as well as fir growing at higher altitudes at warmer SW- 
slopes. Without considering the topographic variability in temperature, simulated natural vegetation is only determined by altitudinal zonation, which does not allow a complex of two forest communities at the same altitude.

Minimum temperature in winter $(m i W T)$ : Selection of the minimum local monthly temperature of the year (LT').

Annual Sum of degree days (DDS):

$$
\mathrm{DDS}=\operatorname{sum}\left(\max \left(\left(\mathrm{LT} \mathrm{T}^{\prime}-\mathrm{dtt}\right), 0\right){ }^{*} 30.5\right) \quad\left[{ }^{\circ} \mathrm{C} * \text { days }\right]
$$

[Equation A7]

LT': local temperature $\left[{ }^{\circ} \mathrm{C}\right]$

dtt: development threshold for vegetation $\left(5.5^{\circ} \mathrm{C}\right.$ after LandClim)

30.5: average number of days per month

Growth reduction according to number of degree days (DDred): The local annual number of degree days DDS is related to the species specific interval ]miDD, maDD[ (see Table A1) using the parabolic equation after Botkin, cited in Bugmann (1994).

Apparent altitude (AA): The apparent altitude is a proxy for the general level of temperature climate, which drives successions in the herb layer and shrub establishment (via the altitude effect, see Gillet 2008). A decrease in AA positively influences fallow succession in the herb layer dynamics and shrub recruitment (Gillet 2008) and enhances the forage production of the herb layer expressed in $\mathrm{kg}$ dry matter per year (see section herb layer). We reformulated the calculation of AA in order to consider a delayed adaptation of vegetation to temperature rise. We introduced the average yearly temperature during the last 50 years Tav50a (dynamically looking back from each simulation year) in order to characterize the temperature level, to which plant communities are adapted. Following climate change, Tav50a rises far slower than mean annual temperatures do. After Equation A8, AA behaves similarly.

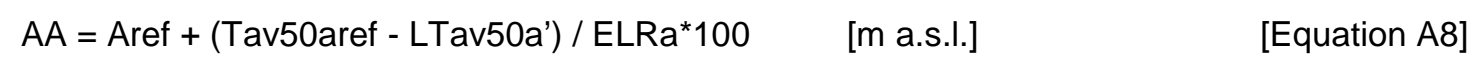

Aref: altitude of the climate reference [m a.s.I.]

Tav50ref: average temperature during the last 50 years at the climate reference $\left[{ }^{\circ} \mathrm{C}\right]$

LTav50a': local average temperature during the last 50 years, corrected for slope-aspect effects $\left[{ }^{\circ} \mathrm{C}\right]$

ELRa: yearly average elevation lapse rate of temperature $[0.5 \mathrm{~K}$ per 100 meters)

Length of the growing season (vegdays): The length of the growing season drives the productivity of the herb layer (see section herb layer). Here we also assume a slow adaptation of mountain grasslands to the productivity of lowland pastures and calculate vegdays from the apparent altitude as follows (Equation A9):

$$
\text { Vegdays }=320 * \exp (-0.0006 * A A) \quad[\text { days }]
$$

AA: apparent altitude [m a.s.I.] 
Drought stress response factor (dReff): The yearly drought stress response factor dReff relates annual drought index DrI to the drought tolerance of tree species dst (see Table A1) following Bugmann (1994, p. 66) (Equation A10).

$$
\mathrm{dReff}=\operatorname{sqrt}(\max (1-(\operatorname{Drl} / \mathrm{dst}), 0))
$$

[Equation A10]

The drought stress response factor ranges between 0 and 1 and is directly applied to tree growth as a multiplier hindering transitions between life stages. Establishment of trees is hindered if drought stress index DrI exceeds the species-specific drought tolerance dst.

Annual drought index DrI: Following LandClim, DrI is the average of the monthly drought index DrIm, calculated for the (variable) vegetation period for evergreen species (development threshold $\mathrm{dtt}=5.5^{\circ} \mathrm{C}$ ) and for the months April to October for deciduous species (Bugmann 1994) (Equation A11).

$$
\begin{aligned}
\text { Drl_evergreen }= & \text { sum }\left(\text { if }\left[\mathrm{LT}^{\prime}\right]>=\mathrm{dtt} \text { then }[\mathrm{Drlm}] \text { else } 0\right) \\
& \text { /howmanytrue }\left(\left[\mathrm{LT}^{\prime}\right]>=\mathrm{dtt}\right) \\
\text { Drl_deciduous }= & \text { sum }\left(\text { if element }\left(\left[\mathrm{LT} T^{\prime}\right],[4,5,6,7,8,9,10]\right)>=\mathrm{dtt}\right. \\
& \text { then element }([\mathrm{Drlm}],[4,5,6,7,8,9,10]) \text { else } 0) \\
& \text { /howmanytrue }\left(\text { element }\left(\left[\mathrm{LT}^{\prime}\right],[4,5,6,7,8,9,10]\right)>=\mathrm{dtt}\right)
\end{aligned}
$$

[Equation A11]

Following LandClim again, the monthly drought index DrIm is based on the ratio of actual transpiration of trees ETt and evaporative demand of trees Tdt (Equation A12). When actual evapotranspiration is smaller than the evaporative demand, the tree suffers drought stress.

$$
\text { Drlm }=1-\mathrm{ETt} / \mathrm{Tdt}
$$

[Equation A12]

The evaporative demand Tdt is conceptually calculated after LandClim (Equation A13):

$$
\begin{aligned}
& \mathrm{Td}=\mathrm{PET}-\text { Interc } \quad[\mathrm{mm}] \\
& \text { PET: potential evapotranspiration }[\mathrm{mm}] \\
& \text { Interc: interception [mm] }
\end{aligned}
$$

[Equation A13]

In order to approximate the hydrological situation in semi-open landscapes, which varies with tree cover and is different from closed forests, we implemented a separate calculation of interception in grasslands and in forest (Equation A14):

$$
\begin{aligned}
\text { Interc }= & \text { TreeCover }{ }^{*} \min \left(0.3^{*}[\text { Pvar] }],[\text { PET }]\right) \\
& +(1-\text { TreeCover }-\mathrm{RO}){ }^{*} \min \left(0.15^{*}[\text { Pvar }],[\mathrm{PET}]\right) \quad[\mathrm{mm}] \quad \text { [Equation A14] }
\end{aligned}
$$

Pvar: monthly precipitation derived from the (stochastically varied) reference climate time series [mm]

RO: cover of rock outcrops in a grid cell

We assumed no interception on rock face, 30\% interception in forest (Lyr et al. 1992) and $15 \%$ interception on grassland (Couturie and Ripley 1973, Ripley and Saugier 1978, Kelliher et al. 1993). 
Potential evapotranspiration is calculated after Pike (1964) (Equation A15):

$\mathrm{PET}=\mathrm{kpMod}{ }^{*} \max \left(0.4^{*}[\mathrm{LT}] /([\mathrm{LT}]+15)^{*}\left(50+[\operatorname{lga}]^{*}\left(0.18+0.62^{*} 0.5\right)\right), 0\right)$

[Equation A15]

kpMod: correction factor for PET regarding slope-aspect influence (see (Schumacher 2004)) LT: first estimate of local monthly temperature $\left[{ }^{\circ} \mathrm{C}\right]$

Iga: solar radiation, which accounts for a latitudinal adjustment of PET values [cal/ $/ \mathrm{cm}^{2} /$ day]

While LandClim derives actual transpiration of trees ETt from a soil water balance, we calculate ETt applying an equation from hydrologcal science based on the aridity index AIP, which was originally developed to assess the water balance in river catchments on a yearly basis (Zhang et al. 2001). Zhang's formula considers differences in actual evapotranspiration between grassland and forest across a gradient of aridity and was validated for grasslandforest-mosaics at catchment scale. In order to estimate the actual evapotranspiration of trees ETt dynamically from the monthly climate given by temperature and precipitation, we apply the equation after Zhang et al. (2001) at a monthly basis and parameterize for forest (plant available water coefficient $\omega$ set to 2, Equation A16):

ET_trees $=\max \left([\mathrm{Pvar}]^{*}\left(1+2^{*}[\mathrm{AIP}]\right) /\left(1+2^{*}[\mathrm{AIP}]+1 /[\mathrm{AIP}]\right)^{*}(1-\mathrm{RO})^{\wedge}(1 / 2), 0\right) \quad$ [Equation A16]

AIP: aridity index, calculated as follows:

AIP = PET / Pvar

Rock outcrops are applied as an arbitrary modifier to ETt subject to calibration and based on the fact that trees on shallow soils associated with rock outcrops can transpirate less due to low water resources in the soil. By this means, reduced ETt leads to enhanced drought stress DrIm of such trees, which negatively impacts on establishment and growth. The exponent $1 / 2$ applied to the inverse rock cover in a grid cell (1-RO) expresses the provision of water for tree establishment and growth by cracks and soil-filled pockets in the rock face, which can be sufficient unless the cover of rock face becomes very high. Choosing $1 / 2$ is due to optimization (see sensitivity analysis at the end of the appendix).

\section{The cattle submodel}

For browsing intensity in the herb layer, additionally to fallows (tall unpalatable forbs) and rock outcrops (see Gillet 2008), we consider shrubs to protect seedlings similarly. Mostly thorny shrubs act as nursery plants and protect seedlings from browsing. Browsing intensity in the herb layer is calculated from the grazing intensity, the tree species specific resistance to browsing and the presence of protecting vegetation as follows (Equation A17):

$\mathrm{Blh}=\mathrm{GI}^{\wedge} \mathrm{bp}$ * $\mathrm{BCh} *(1-\mathrm{F}-\mathrm{RO}){ }^{*}(1-\mathrm{S})$

[Equation A17]

GI: local grazing intensity (Gillet 2008)

bp: resistance to browsing (see Table A1 species parameters)

BCh: cover of seedlings in the herb layer

$\mathrm{F}$ : cover of fallow in a grid cell

RO: cover of rock outcrops in a grid cell

$\mathrm{S}$ : cover of shrubs in a grid cell. 
For all scenarios that shall consider current management practices (climate change scenarios starting from today), a rotational grazing system is simulated based on a division of each pasture into several paddocks. Approximating adaptive agricultural practice, the grazing duration per paddock $\mathrm{GD}_{\mathrm{i}}$ of the herd is optimized according to the forage production of the paddock $\mathrm{FP}_{\mathrm{i}}$ relative to all paddocks of the pasture (Equation A18):

$$
\mathrm{GD}_{\mathrm{i}}=\mathrm{GD}_{\text {year }}{ }^{*}\left(\mathrm{FP}_{\mathrm{i}} / \mathrm{FP}_{\text {pasture }}\right)
$$

[Equation A18]

$G_{\text {year }}$ : total grazing duration of the pasture per year (in mountain pastures around 120 days) $\mathrm{FP}_{\text {pasture: }}$ sum of the forage production of all paddocks $[\mathrm{kg} \mathrm{DM} / \mathrm{y}]$ 


\section{Sensitivity analysis of drought stress calculation for trees on shallow soils}

Beside forage productivity of the herb layer, drought stress on tree growth is the most important driver of simulated landscape structural changes. Future summer droughts obviously select potentially dominant tree species from the species pool dependent on the degree of climate warming and the shift in the precipitation regime.

\section{Design}

We performed a sensitivity analysis on our estimate of drought stress on trees, focusing on our method to consider soil water availability (see above), which differs from the established method in the forest landscape model LandClim (Bugmann 1994, Schumacher 2004, Schumacher and Bugmann 2006). We performed comparative simulations of vegetation development in the mountain pasture Pré aux Veaux, where rock outcrops are frequent due to ridges of limestone. Simulations run from 1950 (spin-up based on observed climate) until 2500 along the moderate climate change scenario B2. We varied the influence of rock outcrops (RO) in the drought stress estimation for trees. We use the cover of rock outcrops, which was estimated from geomorphology as an indicator for shallow soils (see above). Drought stress for trees is accordingly increased applying the following modifier (Equation A19):

RO: Cover of rock outcrops in a grid cell expRO: shape factor for the strength of influence of shallow soils on drought stress

The shape factor expRO for the influence of shallow soils on drought stress was set to values of 0 (no effect), 0.5 (reduced effect), 1 (linear effect) and 2 (enhanced effect). A reduced effect was based on the hypotheses, that for trees there is still water provided in cracks unless the rockface reaches a high proportion of area. An enhanced effect could be assumed considering shallow soil already dominating the soil water household when the cover of rock outcrops is little.

\section{Results}

While simulated values of drought stress hardly differ (not shown), impacts on population dynamics of tree species and landscape structure are clearly noticeable (Figure A1):

When disregarding geological and pedological conditions in drought stress calculations $(\operatorname{expRO}=0)$, Spruce initially profits from climate warming and disappears, because it is outcompeted by beech in the long run.

When distinguishing between shallow and deep soils $(\operatorname{expRO} \neq 0)$, dependent on the strength of the drought effect, tree growth is slowed in general and an intermediate forest breakdown results by the slow replacement of spruce by beech (see diagram for Phy4 (closed forest) in Figure A1). Most interesting, however, is the two-peak pattern in the population dynamics of spruce:

Currently (at simulation start) spruce is growing on rocky ridges, where it declines suffering drought with climate warming from 2100 on. Reduced browsing pressure due to increased forage availability after warming, however, allows spruce to establish on formerly intensively grazed and treeless deep soils. Here it can grow well and spruce recovers until it is outcompeted by immigrating beech. 
Fluctuations of AIL (see Figure A1) underpin quite rapid dynamics of forest cover: As long as spruce dominates the landscape, its sensitivity to drought makes the landscape vulnerable to drought events, which act as disturbances and in turn create a heterogeneous and dynamic landscape. AIL stabilizes at a high value after beech became dominant, indicating a stable and homogeneous landscape pattern.

\section{Conclusion}

We decided to implement the reduced drought effect on shallow soils $(\operatorname{expRO}=0.5)$ into the model in order to carefully avoid exaggeration of an effect hard to be clearly validated based on field data. We reject the null model (no effect: expRO $=0$ ), because spruce suffering from drought on exposed ridges of limestone is plausible, as well as its good growth on sites with a favorable water household (deposits of loess). We think that the simulated effects at landscape level, which arise from the explicit consideration of different geological site conditions (temporary forest breakdown), are important to be considered in management decisions.
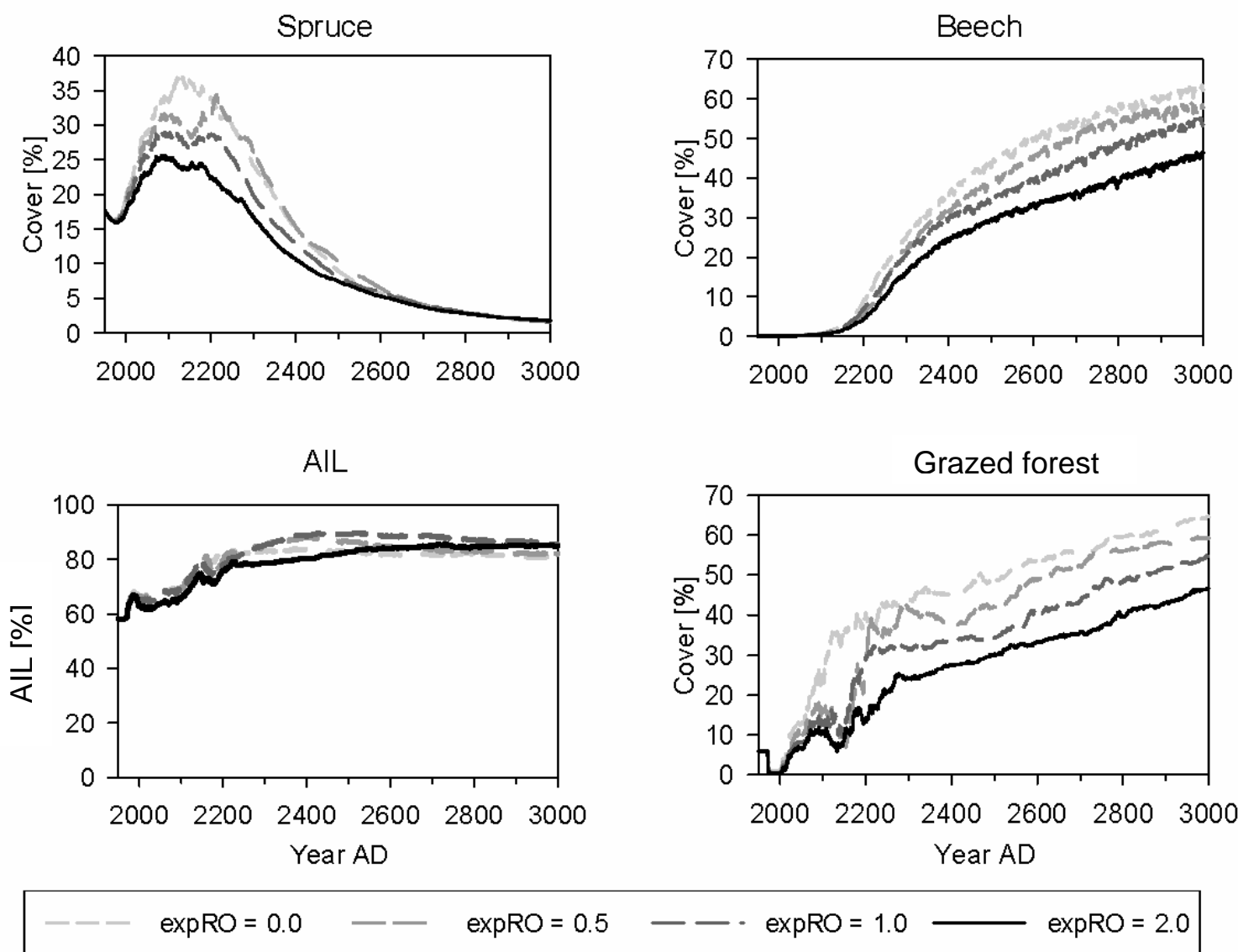

Figure A1: Population dynamics of spruce and beech and corresponding landscape structural dynamics for varying strength of the effect of shallow soils on drought stress for trees. All simulations are performed in the mountain pasture Pré aux Veaux along the moderate climate change scenario B2. The AIL is the landscape structure aggregation index (see main text) with high values indicating a homogeneous landscape. 
Table A1. Tree species parameters. Parameters with an asterisk $\left(^{*}\right)$ are adapted to oceanic climate as described in the text.

\begin{tabular}{|c|c|c|c|c|c|c|c|c|c|c|c|c|c|c|c|c|c|c|c|c|c|c|c|c|}
\hline 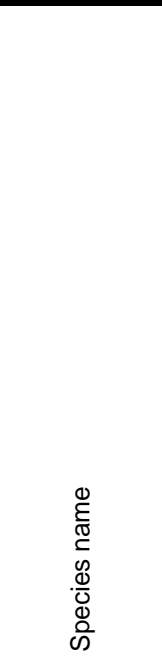 & 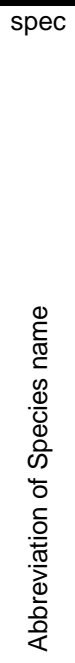 & 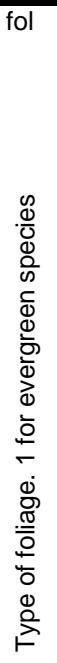 & 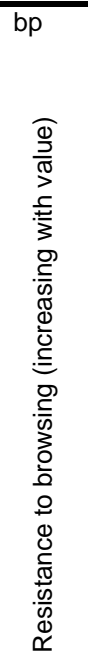 & 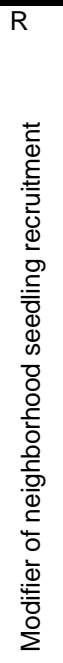 & 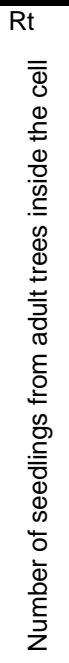 & 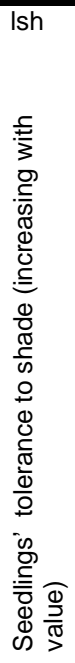 & 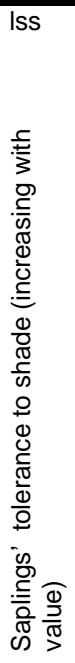 & 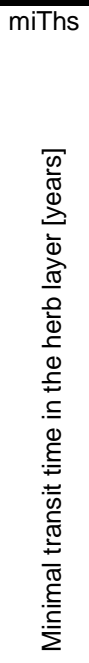 & 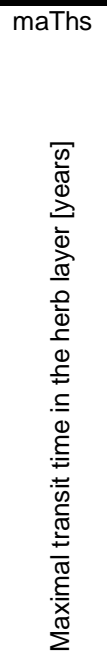 & 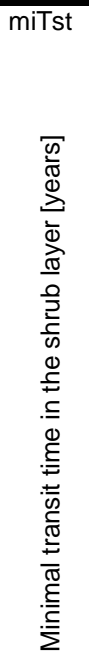 & 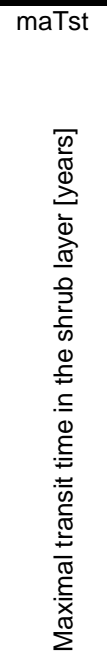 & 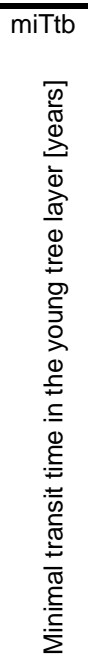 & 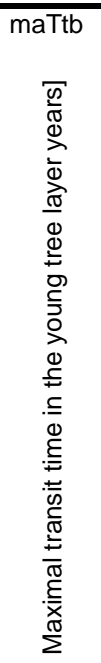 & 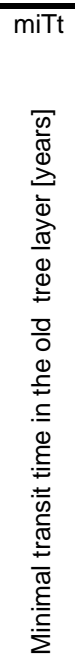 & 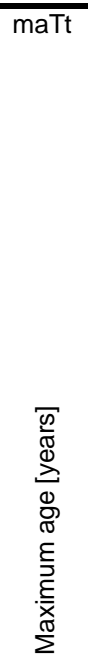 & 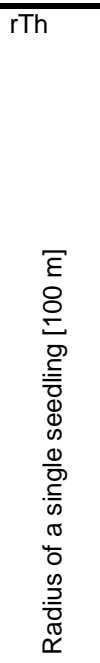 & 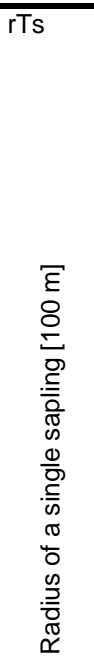 & 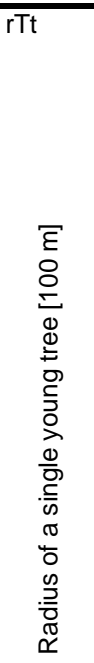 & 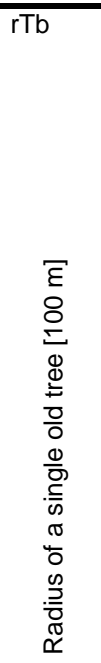 & 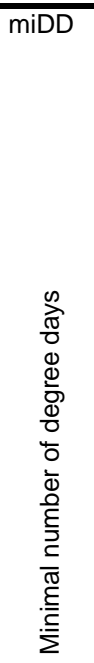 & 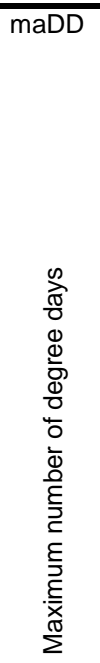 & 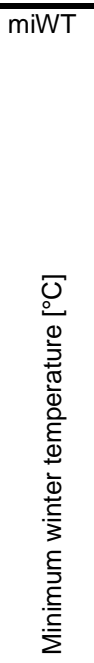 & 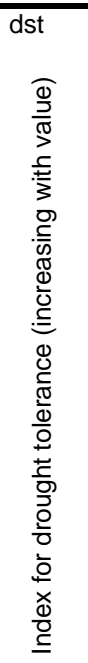 & 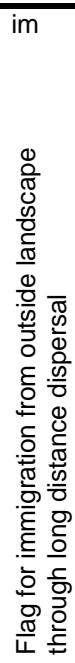 \\
\hline Picea abies & $\mathrm{Pa}$ & 1 & 2 & 5 & 3 & 0.5 & 0.5 & 12 & $12.5^{\star}$ & 8 & 80 & 10 & 30 & 100 & 930 & 0.001 & 0.004 & 0.008 & 0.024 & 385 & 2325 & $-3.9^{*}$ & 0.15 & 1 \\
\hline $\begin{array}{l}\text { Acer } \\
\text { pseudoplata } \\
\text { nus. }\end{array}$ & Ap & 0 & 1 & 10 & 4 & 0.6 & 0.7 & 2 & 4 & 10 & 20 & 8 & 20 & 80 & 550 & 0.001 & 0.005 & 0.012 & 0.036 & $514^{*}$ & 4491 & -273 & 0.17 & 1 \\
\hline $\begin{array}{l}\text { Fagus } \\
\text { sylvatica }\end{array}$ & Fs & 0 & 0.75 & 50 & 4 & 0.7 & 0.9 & 5 & 6 & 10 & 50 & 10 & 50 & 80 & 430 & 0.001 & 0.006 & 0.016 & 0.048 & $514^{*}$ & 4655 & $-4^{*}$ & 0.25 & 1 \\
\hline Abies alba & $\mathrm{Aa}$ & 1 & 0.25 & 30 & 3 & 0.7 & 0.9 & 5 & 6 & 10 & 40 & 10 & 50 & 80 & 700 & 0.001 & 0.004 & 0.008 & 0.024 & 641 & 4491 & -6 & 0.23 & 1 \\
\hline $\begin{array}{l}\text { Pinus } \\
\text { sylvestris }\end{array}$ & Ps & 1 & 0.5 & 5 & 3 & 0.3 & 0.1 & 2 & 4 & 10 & 20 & 8 & 20 & 60 & 760 & 0.001 & 0.005 & 0.012 & 0.036 & $1094^{*}$ & $4500^{*}$ & -273 & 0.37 & 1 \\
\hline $\begin{array}{l}\text { Quercus } \\
\text { petraea }\end{array}$ & Qp & 0 & 0.75 & 50 & 4 & 0.4 & 0.3 & 4 & 6 & 10 & 30 & 10 & 40 & 100 & 860 & 0.001 & 0.006 & 0.016 & 0.048 & 785 & 4655 & -5 & 0.25 & 1 \\
\hline $\begin{array}{l}\text { Quercus } \\
\text { robur }\end{array}$ & Qr & 0 & 0.75 & 50 & 4 & 0.3 & 0.1 & 4 & 6 & 10 & 30 & 10 & 40 & 100 & 1060 & 0.001 & 0.006 & 0.016 & 0.048 & 1042 & 4655 & -17 & 0.17 & 1 \\
\hline $\begin{array}{l}\text { Quercus } \\
\text { pubescens }\end{array}$ & Qh & 0 & 0.75 & 50 & 3 & 0.3 & 0.3 & 5 & 8 & 10 & 30 & 15 & 50 & 90 & 500 & 0.001 & 0.005 & 0.012 & 0.036 & 1011 & 4655 & -273 & 0.41 & 1 \\
\hline $\begin{array}{l}\text { Carpinus } \\
\text { betulus }\end{array}$ & $\mathrm{Cb}$ & 0 & 0.5 & 20 & 4 & 0.6 & 0.7 & 2 & 4 & 10 & 40 & 8 & 50 & 60 & 220 & 0.001 & 0.004 & 0.012 & 0.036 & 898 & 4655 & -9 & 0.25 & 1 \\
\hline $\begin{array}{l}\text { Fraxinus } \\
\text { excelsior }\end{array}$ & $\mathrm{Fe}$ & 0 & 0.5 & 10 & 4 & 0.6 & 0.7 & 2 & 4 & 10 & 20 & 8 & 20 & 60 & 350 & 0.001 & 0.005 & 0.012 & 0.036 & 980 & 4491 & -17 & 0.08 & 1 \\
\hline $\begin{array}{l}\text { Tilia } \\
\text { platyphyllos }\end{array}$ & $\mathrm{Tp}$ & 0 & 0.5 & 20 & 3 & 0.6 & 0.7 & 2 & 4 & 10 & 30 & 8 & 20 & 60 & 960 & 0.001 & 0.005 & 0.012 & 0.036 & 1339 & 4491 & -273 & 0.25 & 1 \\
\hline $\begin{array}{l}\text { Acer } \\
\text { campestre }\end{array}$ & Ac & 0 & 0.5 & 10 & 3 & 0.5 & 0.5 & 2 & 4 & 10 & 30 & 8 & 20 & 50 & 170 & 0.001 & 0.004 & 0.012 & 0.036 & 1062 & 4491 & -273 & 0.25 & 1 \\
\hline $\begin{array}{l}\text { Sorbus } \\
\text { aucuparia }\end{array}$ & Sa & 0 & 1 & 5 & 4 & 0.4 & 0.3 & 2 & 6 & 10 & 20 & 8 & 20 & 50 & 110 & 0.001 & 0.004 & 0.012 & 0.036 & 498 & 4204 & -273 & 0.33 & 1 \\
\hline
\end{tabular}


Table A2: Parameters of WoodPaM, which have been newly introduced since Gillet (2008) and which are not given in Table A1. Parameters are listed in alphabetical order.

\begin{tabular}{|l|l|c|}
\hline Parameter & Explanation & Unit \\
\hline AIP & Aridity index & - \\
\hline Aref & Altitude of the reference climate station & $\mathrm{m}$ a.s.I. \\
\hline DDred & Growth reduction according to number of degree days (Bugmann 1994) & - \\
\hline DDS & Annual number of degree days & Days \\
\hline dReff & Drought stress response factor & - \\
\hline Drl & Annual drought stress index (see chapter climate submodel) & - \\
\hline Drlm & Monthly drought index & - \\
\hline Dtt & Development threshold for vegetation & $5.5^{\circ} \mathrm{C}$ \\
\hline ELR & Month-specific elevation lapse rate of temperature & $\mathrm{K} / 100 \mathrm{~m}$ \\
\hline ELRa & Yearly average elevation lapse rate of temperature & $0.5 \mathrm{~K} / 100 \mathrm{~m}$ \\
\hline ETt & Actual evapotranspiration of trees & $\mathrm{mm}$ \\
\hline Iga & Solar radiation energy, which accounts for a latitudinal adjustment of PET values & $\mathrm{cal} / \mathrm{cm} 2 / \mathrm{day}$ \\
\hline Interc & Interception & $\mathrm{mm}$ \\
\hline kpMod & Correction factor for PET from LandClim (Schumacher 2004) & - \\
\hline LT and LT' & Local temperatures at grid cell level. & ${ }^{\circ} \mathrm{C}$ \\
\hline LTobs & Average local temperature calculated from the observed climate time series of the years $1901-$ & \\
\hline PET & Pootential evapotranspiration & $\mathrm{mm}$ \\
\hline Pvar & Monthly precipitation & $\mathrm{mm}$ \\
\hline
\end{tabular}




\section{LITERATURE CITED}

Béguin, D. 2007. Tree regeneration and growth in wood pastures: patterns and processes. $\mathrm{PhD}$ Thesis. University of Neuchâtel, Neuchâtel.

Bugmann, H. 1994. On the ecology of mountainous forests in a changing climate: a simulation study. PhD. Swiss Federal Institute of Technology, Zurich.

Couturier, D. E. and E. A. Ripley. 1973. Rainfall Interception in Mixed Grass Prairie. Canadian Journal of Plant Science 53:659-663.

Ellenberg, H. 1996. Vegetation Mitteleuropas mit den Alpen. 5. Auflage. Eugen Ulmer, Stuttgart.

Gavazov, K., A. Peringer, F. Gillet, S. Siehoff, A. Buttler, and T. Spiegelberger. 2012. Dynamics of forage production in pasture-woodlands of the Swiss Jura Mountains under projected climate change scenarios. Submitted to Ecology and Society.

Gillet, F. 2008. Modelling vegetation dynamics in heterogeneous pasture-woodland landscapes. Ecological Modelling 217:1-18.

Kelliher, F. M., R. Leuning, and E. D. Schulze. 1993. Evaporation and Canopy Characteristics of Coniferous Forests and Grasslands. Oecologia 95:153-163.

Lyr, H., H.-J. Fiedler, and W. Tranquillini. 1992. Physiologie und Ökologie der Gehölze. Gustav Fischer Verlag Jena.

Martignier, L., T. Adatte, and E. P. Verrecchia. Bedrock versus superficial deposits in the Swiss Jura Mountains: what is the legitimate soil parent material? Earth Surface Processes and Landforms, in press.

Pike, J. G. 1964. The Estimation of Annual Run-off from Meteorological Data in a Tropical Climate. Journal of Hydrology 2:116-123.

Rickebusch, S., H. Lischke, H. Bugmann, A. Guisan, and N. E. Zimmermann. 2007. Understanding the low-temperature limitations to forest growth through calibration of a forest dynamics model with tree-ring data. Forest Ecology and Management 246:251-263.

Ripley, E. A. and B. Saugier. 1978. Biophysics of a Natural Grassland - Evaporation. Journal of Applied Ecology 15:459-479.

Schumacher, S. 2004. The role of large-scale disturbances and climate for the dynamics of forested landscapes in the European Alps. PhD. Swiss Federal Institute of Technology, Zurich.

Schumacher, S. and H. Bugmann. 2006. The relative importance of climatic effects, wildfires and management for future forest landscape dynamics in the Swiss Alps. Global Change Biology 12:1435-1450. 
Zhang, L., W. R. Dawes, and G. R. Walker. 2001. Response of mean annual evapotranspiration to vegetation changes at catchment scale. Water Resources Research 37:701-708. 